\title{
Ultrasound-Mediated Gene Delivery
}

\author{
Carol H. Miao and Andrew A. Brayman \\ Seattle Children's Research Institute \& University of Washington, Seattle WA \\ United States of America
}

\section{Introduction}

Human gene therapy holds great promise in treating not only hereditary genetic disorders, but also disease states such as cancer and viral infections, and contingencies such as stroke or myocardial infarctions. It can be achieved by delivery of a correct gene into target cells with genetic deficiency or mutations, or by transfer of a therapeutic agent such as agents targeting a cancer-causing oncogene, growth factor gene, antisense oligonucleotides (ODN), or small interfering RNA (siRNA) to correct the disease state using either viral or nonviral vectors. Viral gene therapy has succeeded in many animal disease models \{Snyder 1999\}, and has progressed to clinical trials \{Hacein-Bey-Abina et al. 2002; Kay et al. 2000\}. However, significant obstacles remain, including immune responses \{Manno et al. 2006\} or tumor genesis \{Hacein-Bey-Abina et al. 2003\}. A nonviral approach would provide a safer strategy. The potential for therapeutic ultrasound (US) to effect minimally invasive nonviral gene transfer has long been recognized, and a growing body of evidence indicates that significant enhancement of transgene expression can be achieved by using high frequency acoustic energy. In addition to its well-known role in providing inexpensive, real-time imaging capability, US has been used therapeutically for years \{Herzog et al. 1999\}. The most common therapeutic application involves low acoustic intensities and is intended to heat deep tissues; e.g., as used in sports medicine. At the other 'end' of the acoustic intensity spectrum is HIFU (high intensity focused ultrasound), which can be used to ablate \{Fischer et al. 2010\} or to liquefy tissues \{Hall et al. 2009\}. US of intermediate intensities has been applied to many systems, together with exogenous microbubbles [MBs], to use the acoustically-forced behavior of the MBs to generate desired bioeffects. The latter usually involves changing the permeability of endogenous barriers to otherwise impermeable materials (e.g., drugs or macromolecules). Many gene therapies have been attempted by direct intramuscular or intraparenchymal injection of gene vectors; these vectors gain immediate access to the interstitial space and must then traverse the plasma membrane of the targeted cells. US contrast agents are almost always administered intravascularly. When accompanied by a gene vector, the first barrier encountered is the vascular endothelium. The next are other vascular anatomical features (e.g., the basement membrane, smooth muscle layer, etc.) and then the outer cell membrane of the cells one hopes to target. Finally, DNA needs to be transferred across the nuclear membrane to enter the nucleus for efficient gene expression.

This review will focus almost entirely on the use of ultrasound targeted microbubble destruction (UTMD) as a means by which to deliver foreign DNA (or drugs or photo 
reactive nanoparticles, as other examples for which there are numerous publications) into targeted host tissues and cells. The literature on this topic is growing at an incredible rate, because almost immediately following the commercial availability of microbubble-based US contrast agents in the 1980s, it was recognized that acoustic cavitation could cause potentially undesirable bioeffects, desirable ones, or both.

Exploitation of acoustically-activated MBs for therapeutic effect remains an exciting topic. Indeed, harnessing the dynamical behavior of acoustic MBs is somewhat of the 'holy grail' of acoustically-targeted gene (or drug) delivery \{Lindner 2009\}. However, a healthy skepticism has been (see, e.g., \{Villanueva 2009\} and should continue to be, applied to claims of great successes achieved using UTMD, as replication studies are few, and contradictory findings not unusual. Skepticism should obtain especially when considering 'black box' US studies.

A reasonably coherent picture of US-mediated gene therapy is emerging. With UTMD techniques, the issue ultimately reduces to the fact that US can force dynamic behaviors of MBs. Endogenous MBs are absent in most tissues of the body \{Carstensen et al. 2000; Gross et al. 1985\}. Exogenously-administered MBs are generally inert without acoustic exposure, but can be made to pulsate gently, or to undergo violent but highly localized dynamic behavior when driven by acoustic fields. Targeting can thus be achieved by methods as simple as co-administering MBs and gene vectors and exposing the targeted tissue to US, which will thus be the only site where bubble activation occurs. As we shall see, bioeffects typically arise when MBs are driven at pressure amplitudes sufficient to produce nonlinear bubble oscillations.

Here we will discuss the issues broadly, in the hope that the reader will gain a general understanding of the techniques, applications, apparent mechanisms, and some insights into what has been achieved. We focus most of our discussion on in vivo studies, as US-assisted gene therapy in vivo continues to be a more challenging problem than US-enhanced cell permeabilization in vitro or even in intact ex vivo tissues (see; e.g. \{Kodama et al. 2005\}). We have striven to be as jargon-free as possible, and have neglected mathematical treatments of the topics discussed here, as these can be found elsewhere. A few simple abbreviations are used: US (ultrasound); $\mathbf{M B}$ (microbubble); $\mathbf{P}_{\mathbf{a}}$ or $\mathbf{P}_{\mathbf{r}}$ (acoustic pressure amplitude or rarefaction pressure, respectively); and pDNA (plasmid DNA). Some words on US exposure metrics are also necessary. In some applications of therapeutic US (e.g., tissue heating), the acoustic intensity in dimensions of $\mathrm{W} / \mathrm{cm}^{2}$ is the parameter of interest. In contrast, the occurrence and character of acoustic cavitation in vivo is largely determined by the presence or absence of exogenous MBs and by peak acoustic intensity, or more properly, by the peak acoustic pressures. These are expressed in units of mega- (MPa) or kiloPascals $(\mathrm{kPa})$, where $1 \mathrm{MPa}=10 \mathrm{~atm}$. Acoustic intensity scales as the square of the pressure amplitude. The quality of acoustic reporting in the US-mediated gene therapy literature varies widely. We will describe most acoustic exposures in terms of the pressure amplitude $\left(\mathrm{P}_{\mathrm{a}}\right)$ or the peak rarefactional acoustic pressure $\left(\mathrm{P}_{\mathrm{r}}\right)$, sometimes inferred by us. In any case, it is not our purpose here to be rigorously quantitative.

\section{Ultrasound-targeted microbubble destruction: Physics \& technology}

There are many potential applications for UTMD gene delivery; a large body of work has been conducted using both in vitro and in vivo model systems to understand if, and how, UTMD 'works' to produce therapeutic effects. Most studies have as their ultimate goal the application of the technology to effect minimally-invasive treatment of disease or 
contingency, although in vitro UTMD transfection techniques are being used for cell-based therapies \{Otani et al. 2009\}. Specific applications to various organs or for various clinical conditions will be discussed in §5. Here it is sufficient to note that in UTMD-based gene delivery studies, much of the work has focused on model or surrogate systems; e.g., the delivery of reporter genes rather than therapeutic ones. However, therapeutic gene transfer effects such as tumor volume reduction have been reported in some model systems.

Therapeutic US has the potential for enhancing minimally invasive gene therapies. For gene therapies involving naked DNA vectors in particular, UTMD techniques have many desired characteristics. These include (1) low toxicity of all components of the treatment, (2) low immunogenicity of the vectors, (3) low invasiveness (e.g., the vector and gas bodies can be administered intravascularly, and for sonographically-accessible organs, the therapeutic US can be applied through the skin), (4) there is good potential for repeated application, (5) organs can be targeted with high specificity, and (6) the technique has broad applicability (again related to sonographic accessibility). However, low efficiencies remain a problem.

\subsection{What is ultrasound targeted microbubble destruction?}

Here we hope to provide a sense of the types of MBs often used in US-mediated gene therapies, the ways in which US can cause these MBs to be destroyed (either gradually or abruptly) and/or otherwise activated, and the mechanisms by which UTMD-induced microvascular damage, extravasation, and target cell uptake of gene vectors may occur. A more comprehensive discussion of the physics can be found in $\{\mathrm{Wu} \&$ Nyborg 2008\}.

In broad terms, the targeting 'part' of UTMD therapies is based principally on the fact that MBs present in tissues respond dynamically only if the area is exposed to US. Ligands incorporated into the MB shell may enhance accumulation of the MBs and any vector load they carry in a region of interest, but it is the selective acoustic exposure which 'activates' the MBs. As mentioned, site-specific ligands can be added to MB shells to improve retention in regions of interest. This field has received considerable attention \{Ferrara et al. 2009\}. Some degree of targeting can also be achieved by acoustically 'pushing' bubbles to a region of interest. A propagating acoustic field exerts a radiation force on MBs \{Sarvazyan et al. $2010\}$, and this force can propel them in the direction of wave propagation. If the MB is undergoing radial oscillations \{Emmer et al. 2007\}, the bubble lurches forward, slowing as it expands and accelerating as it collapses. Radiation force can be used to concentrate MBs along a specific wall of an intracavitary space $\{$ Horie et al. 2010\}, or blood vessel.

The MB destruction 'part' of UTMD occurs in response to the acoustic exposure, and may result in release of lipid or aqueous-phase drugs \{Smith et al. 2010\} or produce small-scale damage to microvessels which allows normally impermeable materials (drugs, plasmids, even objects as large as cells or MB fragments) to escape the vascular lumen and enter the interstitial space. Cellular permeabilization is also associated with MB activation.

\subsection{Ultrasound contrast agents and other stabilized gas bodies}

Microbubble US contrast agent evolution from early, agitated saline or sugar solutions to protein-shelled agents containing air to lipid- or polymer-shelled agents using relatively insoluble gases was rapid. The evolution of these agents continues \{Qin et al. 2009\}, as do new applications for them \{Cosgrove \& Harvey 2009\}. US contrast agents are typically micron-sized gas bodies which are stabilized against diffusion by a shell \{Overvelde et al. 2010; Sarkar et al. 2009\}; most contrast agent MBs have mean diameters of $\sim 2 \mu \mathrm{m}$. New 
agents currently under development for imaging or therapy are smaller still, and are considered to be nanobubbles \{Krupka et al. 2009\}. Multi-layered structures in which a gas body stabilized by a lipid monolayer is contained in an aqueous compartment bounded by a lipid bilayer (echogenic liposomes) are also under development. When used for imaging, US contrast agents are unique amongst contrast agents in that they respond dynamically to the signal used to interrogate tissues for their presence. It is this same property that is exploited for UTMD therapies or therapy models.

\subsection{Microbubble destruction: Shell disruption and shell/gas body fragmentation}

There are three principal mechanisms by which US or time can destroy a shelled MB \{Chomas et al. 2001\}. In increasing order of 'violence' to the MBs, these are: (1) static diffusion, in which gas dissolves into the surrounding host fluid. This may be rapid if the bubble is 'free' (without stabilizing shell) or very slow if a stabilizing shell is present; (2) acoustically-forced shell disruption, which leads to accelerated diffusive loss of gas relative to unperturbed shelled bubbles; and (3) shell fragmentation and rapid loss of gas.

A micron-sized free air bubble can be expected to dissolve in water in $\sim 30 \mathrm{~ms}$ \{Sarkar et al. 2009 , which is why relatively insoluble gases such as perfluorocarbons are now used in modern contrast agents, and a stabilizing shell is employed. The principal mechanism by which bubble shell materials stabilize MBs against diffusion is by reducing the surface tension at the bubble surface. Shell properties also affect the dynamic responses and stability of MBs at $\mathrm{P}_{\mathrm{a}}$ below the shell fragmentation threshold \{Emmer et al. 2007; Ferrara et al. 2009\}.

Acoustically-forced $\mathrm{MB}$ dissolution can occur when the $\mathrm{P}_{\mathrm{a}}$ is sufficient to drive $\mathrm{MB}$ oscillations which stretch and compress the shell sufficiently to produce relatively small defects in the shell, which may re-seal \{Huang 2008\}. Very high physical stresses develop in the shells as the MB oscillates, even when the driving pressures are only a few hundred $\mathrm{kPa}$ \{Stride \& Saffari 2003\}. Small shell defects lead to more rapid dissolution of the gas body than would otherwise occur, but complete gas dissolution may require many acoustic cycles \{Smith et al. 2010\}. For examples, Optison MBs exposed to $3.5 \mathrm{MHz}$ US of $\mathrm{P}_{\mathrm{a}}>0.15 \mathrm{MPa}$ undergo accelerated loss of gas, indicating shell compromise (Porter et al. 2006\}. Shell disruption $P_{a}$ thresholds for albumin-stabilized Optison and surfactant stabilized Sonazoid are similar; at $1.1 \mathrm{MHz}$, these are $0.13 \mathrm{MPa}$ or $0.15 \mathrm{MPa}$, respectively. At $3.5 \mathrm{MHz}$, these thresholds are somewhat higher (Optison: $0.48 \mathrm{MPa}$; Sonazoid: 0.58 $\mathrm{MPa})\{C h e n$ et al. 2003\}. Others have reported a somewhat lower threshold (0.15 MPa) for Optison shell disruption at $3.5 \mathrm{MHz}$ \{Porter et al. 2006\}. Likewise, \{Borden et al. 2005\} studied the behavior of lipid monolayer-encapsulated MBs at $2.25 \mathrm{MHz}$ using single-cycle pulses, and found that the $\mathrm{P}_{\mathrm{r}}$ threshold for slow $\mathrm{MB}$ dissolution to be in the range of $0.4-$ $0.6 \mathrm{MPa}$, and the $\mathrm{P}_{\mathrm{r}}$ threshold for $\mathrm{MB}$ fragmentation to be $0.8 \mathrm{MPa}$. A $\mathrm{P}_{\mathrm{a}}$ of around 0.3 $\mathrm{MPa}$ was also found to be the threshold for soft-shelled contrast agent MB disruption \{de Jong et al. 2009\}. Echogenic liposomes also appear to have two pressure thresholds; one associated with compromise of the shell of the interior gas body, and a higher one associated with disruption of the outer lipid bilayer \{Smith et al. 2010\}. Rapid fragmentation occurs on a time scale of microseconds when $\mathrm{P}_{\mathrm{a}}$ is sufficient to buckle and completely rupture the shell \{Marmottant et al. 2005\}, creating free gas bodies which may then dissolve, grow by rectified diffusion, coalesce into larger bubbles, or dissolve, depending stochastically on exposure conditions. 


\subsection{Microbubble dynamics: An overview of how gas bodies respond to ultrasound}

At very low $\mathrm{P}_{\mathrm{a}}$, MB volume oscillations are related linearly to $\mathrm{P}_{\mathrm{a}}$. At modest $\mathrm{P}_{\mathrm{a}}$ s of a few hundred $\mathrm{kPa}$ (or less), $\mathrm{MB}$ volume oscillations become non-linearly related to $\mathrm{P}_{\mathrm{a}}$, with bubble expansion being relatively slow and bubble collapse much faster, being governed by the inertia of the in-rushing surrounding fluid to a greater extent than by the compressive phase of the applied pressure field; hence the phenomenon of bubbles undergoing acoustically-driven expansions followed by rapid, inertially-dominated collapse is termed 'inertial cavitation'. This typically occurs when a MB has been driven by the rarefaction phase of the acoustic wave to a diameter roughly $2-3$ times the initial diameter \{Chomas et al. 2001\}. At very modest $P_{a}$ s, inertial cavitation can be stable and sustained for an almost indefinite number of acoustic cycles. For example, \{Church \& Carstensen 2001\} found that surfactant-coated Sonazoid MBs could undergo repetitive inertial collapses and rebounds when driven by $2.5 \mathrm{MHz}$ US at acoustic pressures greater than about $0.3-0.4 \mathrm{MPa}$; for this agent, irreversible post-collapse fragmentation occurred at a $\mathrm{P}_{\mathrm{a}}$ of $\sim 1.5 \mathrm{MPa}$. Others have reported that a $3 \mu \mathrm{m}$ bubble exposed to $2.25 \mathrm{MHz}$ US can be expected to undergo expansion, inertial collapse, and fragmentation at a $\mathrm{P}_{\mathrm{a}}$ just over $0.3 \mathrm{MPa}$ \{Chomas et al. 2001\}. The albumin-shelled, first-generation US contrast agent Albunex began to emit acoustic signatures characteristic of nonlinear oscillations at acoustic pressures as low as $0.005-0.010$ $\mathrm{MPa}\left\{\right.$ Krishna \& Newhouse 1997\}. At even modest $\mathrm{P}_{\mathrm{a}}$ (e.g., $0.6 \mathrm{MPa}$ at $1 \mathrm{MHz}$ ), some contrast agent bubbles can expand to 10 times or larger than their equilibrium radius; under such conditions, inertial collapse is expected. Fragmentation of the inertially-collapsing bubble occurs at some instant near the time of minimum bubble radius \{Postema \& Schmitz 2007\}. Inertial bubble collapse is so rapid and the gas so compressed that the maximum temperature inside the bubble can reach more than $5000 \mathrm{~K}$ \{Apfel \& Holland 1991\}. Light emissions \{Matula 2003\} and reactive free radicals may be produced \{Okada et al. 2009\}. MB rebound and fragmentation can re-emit acoustic energy at many times the excitation pressures. These emissions also contain higher frequency spectral components which can produce local heating. In the present context, however, it appears that the most important determinant of UTMD gene delivery methods is that bubble expansion and collapse can produce local tissue distortions or damage which are presumed to be the principal mechanism by which microvascular bioeffects become manifest, and target cell permeabilization occurs.

Cavitation bubbles can interact with nearby boundaries; these interactions can produce high velocity fluid jets and induce bubble translation, with the directions of fluid jets and translation depending on the boundary's properties. For rigid boundaries, bubbles closer to the boundary than about twice the fully-expanded radius of the bubble \{Kodama \& Tomita 2000\} may collapse asymmetrically, with a high velocity water jet 'punching through' the bubble and impinging on the rigid boundary. Near rigid, planar boundaries, an oscillating MB translates toward the boundary and if collapse jetting occurs, the jet is directed toward the rigid surface \{Plesset \& Chapman 1971\} with sufficient water hammer pressure to damage the surface \{Blake \& Gibson 1987\}. In vivo, however, this condition would seem rare.

MBs driven to oscillate near pressure release boundaries (an air-water interface, for example), collapse jets which occur are directed away from the boundary, as is the direction of bubble translation \{Chahine 1977; Robinson et al. 2001\}.

Oscillating MBs collapsing near a 'soft', planar boundary (e.g., gels or large vessel walls) also undergo translation and jetting, but the directions of jetting and translation can be either toward or away from the boundary, being determined by bubble size, bubble distance from 
the boundary, and the mechanical properties of the boundary (see. e.g., \{Kodama \& Tomita 2000; Shima et al. 1989\}. Deformation of the elastic boundary stores energy which is 'returned' as the bubble collapses; this creates a hydrodynamic pressure gradient which in turn produces fluid flow away from the elastic boundary. If the pressure gradient is large enough, bubble collapse jets directed away from the boundary, and bubble translation away from the boundary, can result \{Blake \& Gibson 1987\}. Liquid jets were observed in an early experimental study of acoustically forced MB behavior in a $200 \mu \mathrm{m}$ diameter cellulose tube \{Postema et al. 2004\}. In vessel-simulating gel tunnels, at $1.7 \mathrm{MHz}$, the $\mathrm{P}_{\mathrm{a}}$ at which Optison MBs began to emit broadband noise characteristic of inertial collapse and rebound was weakly dependent on tunnel diameter $(\sim 0.8 \mathrm{MPa}$ in $90 \mu \mathrm{m}$ diameter tunnels $v s . \sim 0.6 \mathrm{MPa}$ in $800 \mu \mathrm{m}$ tunnels) \{Sassaroli \& Hynynen 2007\}. Single-MB dynamics observations in actual microvessels were acquired using a rat cecum model; MBs translated toward the vessel walls and a toroidal bubble morphology consistent with the formation of a microjet was observed \{Caskey et al. 2007\}.

Where bioeffects attributable to inertial cavitation occur, cavitation jets directed toward cells or tissues have long been assumed to be causative. Vessel 'stretching' during bubble expansion has also been proposed as a mechanism of vessel damage \{Miao et al. 2008\}. Very high speed imaging of MBs driven to growth and inertial collapse in microvessels of rat mesentery \{Chen et al. 2010; Chen et al. 2011\} indicate that (1) MB collapse jets form frequently in the intravascular environment, (2) jets are typically directed away from the nearest blood vessel wall, (3) blood vessel expansion in response to bubble growth is minimal, and (4) tissues 'follow' the collapsing bubbles such that inward vessel distortions are much greater than outward distortions, with inward vessel wall motion having speeds of $5-10 \mathrm{~m} / \mathrm{s}$ and the events occurring on microsecond time scales. This is perhaps one mechanism by which vessel permeabilization occurs. In any case, permeabilization of biological transport barriers is associated with some cell killing, both in vitro \{Brayman et al. 1999\} and in vivo \{Ferrara 2008; Miller et al. 2011; Price et al. 1998; Skyba et al. 1998\}

Finally, it is worth mentioning that MB-excitation techniques for cellular permeabilization need not use US to achieve MB activation or cell permeabilization; targeted laser illumination can also be used effectively. For a recent research paper on this topic, using a liposome MB contrast agent, see $\{$ Zhou et al. 2010\}.

\subsection{Effect of different shell compositions or agents on gene delivery}

It is difficult to compare the efficacy of different contrast agents in US-mediated gene delivery between different studies, because $\mathrm{MB}$ type, concentration as injected, rate of injection, total dose, animal model, US exposure source, exposure conditions, and even the way the MBs are handled vary widely and can influence outcome. MB concentration is a determinant of UTMD-mediated pDNA expression in mouse liver \{Miao et al. 2005; Shen et al. 2008\}. Different agents have different 'native' concentrations, and agents with similar gas content but dissimilar shells can have different efficacies in enhancing gene delivery under otherwise comparable conditions ( $c f$. effects of Optison and PESDA MBs; \{Pislaru et al. 2003\}). Relatively large differences between contrast agent types in UTMD gene delivery have been observed, but the reasons are not always clear. With equalized MB concentrations and either Optison, SonoVue or Sonazoid contrast agents, UTMD-mediated transfer of phosphorodiamidate morpholino oligomer to a dystrophin-deficient murine heart model induced dystrophin-positive cells in the hearts when harvested 7 days after treatment. 
Optison and Sonazoid were equivalent in effectiveness, producing about four times greater expression than did SonoVue \{Alter et al. 2009\}.

\subsection{Sensitivity of stabilized gas bodies to technique}

Bubbles are buoyant, fragile, can coalesce into larger bubbles, or 'disappear' as gas is lost to diffusion. In many in vivo studies of UTMD, the MBs and gene vectors are infused slowly; this prolongs the time window in which acoustic treatments can occur, but aggravates the problem of time-dependent changes in MB distribution and delivery \{Kaya et al. 2009\}. It is worth noting that MBs can be destroyed by static pressure or tension; an over-pressure of only $\sim 0.3 \mathrm{MPa}$ can destroy them \{Stringham et al. 2009\}. MBs can also be destroyed by drawing up or injecting an MB suspension too rapidly when using a small gauge needle \{Talu et al. 2008\}; thus one can unwittingly alter experimental outcome by 'over-enthusiasm'.

\section{Breaching the physical barriers to gene delivery using ultrasound}

In order to achieve efficient gene expression following ultrasound-mediated gene delivery, multiple barriers need to be overcome to allow pDNA to enter into the nucleus of target cells including penetrating vascular and cellular membranes as well as trafficking through different intracellular compartments.

US contrast agents are intended to be intravascular agents. Whether the gene vector is administered as a simple mixture with the gas body suspension, or is in some way linked to the gas bodies, they are also intravascular agents in vascular UTMD methods. The first barrier encountered is the vascular endothelium. The next are other vascular anatomical features (e.g., the basement membrane, smooth muscle layer, etc.) and then the outer cell membrane of the cells one hopes to target. Some intracellular membranous compartments must also be traversed. However, MBs have been used with intramuscular or intraparenchymal injections of vectors, and some successes reported. In UTMD-based gene transfer methods using vascular approaches, to mediate gene therapy via acoustic excitation, gas bodies must first exert their influence from within the vascular lumen.

Most of the available evidence from in vivo studies indicate that vessel permeabilization effects occur principally in the microcirculation; larger vessels are too robust to be penetrated by cavitation events, even if their vascular endothelium can be effectively destroyed by intraluminal inertial cavitation \{Hwang et al. 2005\}. Extravasation of dyes, nanoparticles or macromolecules through microvessels is almost always accompanied by extravasation of red cells (see below); since these have diameters on the order of $6 \mu \mathrm{m}$, breaches in the endothelial wall can be quite large. However, there is also some evidence that more subtle effects, such as partial opening of the tight junctions between endothelial cells, can also contribute. Assuming that the gene vector escapes the intravascular compartment and enters the interstitium, it must then enter the surrounding cells; thus the plasma membrane is the second major barrier encountered by the vectors. Lethal effects of cavitation occurring in the cardiac microcirculation can extend outward into the myocardium \{Miller et al. 2011\}; there is good reason to expect that sub lethal poration of cells located within a few cell diameters of the intravascular cavitation event(s) also occurs.

\subsection{Extravasation of dyes, nanoparticles and cells}

Evans blue [EB] is an azo dye which binds serum albumin with high affinity, and is normally unable to pass through the endothelium. Extravasation of EB through reversible or 
irreversible capillary modification has been observed in small animal (rat) hearts exposed to low-MHz frequency US with the use of various contrast agent MBs, accompanied by premature ventricular contractions $\left\{\mathrm{Li}\right.$ et al. 2004\}. The effect was sensitive to $\mathrm{P}_{\mathrm{a}}$ (apparent threshold somewhat less than 1.6 $\mathrm{MPa}$ at $1.5 \mathrm{MHz}$ ) and to the concentration of the injected MBs \{Miller et al. 2004\}. The effect appears to be of mechanical origin \{Miller et al. 2004\} With injection of dilute Definity suspensions, extravasation of EB from canine hearts, and cell killing of cardiomycetes within the ultrasonically-interrogated area also occurs under diagnostically realistic exposure conditions \{Miller et al. 2006\}.

Erythrocyte extravasation has been observed in rat kidney glomerular capillaries exposed to diagnostic US with contrast agent MBs in the circulation \{Miller et al. 2010a, Miller et al., 2010b\}; such damage was associated with tissue inflammation at 1 week and fibrosis at 4 weeks \{Miller et al. 2009\}. A threshold $\mathrm{P}_{\mathrm{a}}$ of $\sim 0.8 \mathrm{MPa}$ was indicated \{Miller et al. 2007\}. Glomerular capillary hemorrhage with contrast-enhanced diagnostic US also occurs in large animals (pigs) exposed to $1.5 \mathrm{MHz}, 1.7 \mathrm{MPa}$ US \{Miller et al. 2010\}. Petechial hemorrhage on intestinal blood vessels in an in vivo murine model was observed with the contrast agent Albunex, with apparent $\mathrm{P}_{\mathrm{a}}$ thresholds of $0.4 \mathrm{MPa}$ at $0.4 \mathrm{MHz}, 0.8 \mathrm{MPa}$ at 1.1 $\mathrm{MHz}$, or $2.3 \mathrm{MPa}$ at $2.3 \mathrm{MHz}$; the thresholds were lower with the agent Levovist than with Albunex \{Miller \& Gies 1998a, Miller \& Gies 1998b\}. At $2.25 \mathrm{MHz}$, a threshold $\mathrm{P}_{\mathrm{a}}$ of between 0.85 and $1.0 \mathrm{MPa}$ was indicated for vessel damage in exteriorized rat cremaster muscle containing Definity MBs \{Samuel et al. 2009\}. Similarly, intravital observation of red cell extravasation from rat cremaster muscle capillaries containing MB contrast agent was observed more than a decade ago \{Price et al. 1998; Skyba et al. 1998\}. Microscopic observations of US and MB-induced red cell extravasation have been reported in glass catfish \{Maruvada \& Hynynen 2004\}. In exteriorized rat spinotrapezius muscle, $1 \mathrm{MHz}$ US at a $\mathrm{P}_{\mathrm{a}}$ of $0.75 \mathrm{MPa}$ was shown to result in extravasation of $100 \mathrm{~nm}$ diameter microspheres co-injected with contrast agent MBs \{Song et al. 2002\}. In rats, in vivo exposure of the kidneys following injection of MBs resulted in red cell extravasation from the glomerular capillaries into Bowman's space with an apparent threshold $\mathrm{P}_{\mathrm{a}}$ of $\sim 0.73$ MPa (at $1 \mathrm{MHz}$ ), with nearly $40 \%$ of histological sections taken from the focal plane showing extravasation at a $\mathrm{P}_{\mathrm{a}}$ of $1.8 \mathrm{MPa}$ \{Miller et al. 2007\}. Intravital microscopy and concurrent cavitation detection was used to study the relationship between bubble dynamics and extravasation of red cells from rat cremaster muscle using $2.25 \mathrm{MHz}$ US, and Definity contrast agent infused via the tail vein. Vascular damage and acoustic emissions from the MBs were correlated. The greatest amount of red cell extravasation and the greatest cumulated bubble acoustic emissions occurred at $10 \mathrm{~Hz}$ pulse repetition frequency [PRF], indicating that the time for tissue refill with bubbles following each pulse was $100 \mathrm{~ms}$. In experiments in which pulses were applied at $100 \mathrm{~Hz} \mathrm{PRF}$ and the $\mathrm{P}_{\mathrm{a}}$ varied from $0-2.0 \mathrm{MPa}$, there was no vascular damage at $P_{\mathrm{r}} \leq 0.85 \mathrm{MPa}$, but unambiguous damage occurred at $\mathrm{P}_{\mathrm{r}} \geq 1.0 \mathrm{MPa}$ \{Samuel et al. 2009\}. Finally, there is evidence that low amplitude US induced MB oscillations $\left(1 \mathrm{MHz}, \mathrm{P}_{\mathrm{r}}=0.1 \mathrm{MPa}\right.$, SonoVue bubbles) can increase the permeability of primary endothelial monolayer cultures in vitro. Insonation produced immediate influx of $\mathrm{Ca}^{2+}$ ions into the cells, indicating poration of the endothelial plasma membranes. The effect was essentially abolished by application of catalase, strongly suggesting a role for extracellularly-produced $\mathrm{H}_{2} \mathrm{O}_{2}$ associated with nonlinear bubble oscillations. Moreover, histochemical staining for a protein associated with gap junctions showed an approximately 50\% increase immediately after insonation, but returned to control levels within 30 minutes of insonation \{Juffermans et al. 2009\}. 


\subsection{Transient poration of the cell membrane}

Two mechanisms by which US and MBs facilitate poration of cell membranes are prominent; these are: (1) cavitational; e.g., the opening of transient holes in membranes in consequence to local shear forces exerted on membranes by fluid flow ('micro streaming') around oscillating bubbles, local shock waves (which produce large pressure gradients across a cell), or cavitation microjets, or (2) endocytosis \{Doinikov \& Bouakaz 2010; Walton \& Shohet 2009\}. Other mechanisms have been proposed, of course. However, it appears that shear stresses associated with bubble activation is probably the principal mechanism. A third mechanism by which normally 'tight' physiological barriers may be permeabilized is by sonochemical stimulation.

Transient pores of a few hundred nanometers in diameter and lifetimes of several seconds can be formed in cell membranes by acoustically-driven, single MB oscillations \{Deng et al. 2004; Han et al. 2007; Zhou et al. 2008; Zhou et al. 2009\}. Voltage clamp studies of Xenopus oocytes exposed to $1 \mathrm{MHz}$ US showed that without MBs, there was no change in current at $\mathrm{P}_{\mathrm{r}}$ as high as 1.2 MPa. With Optison MBs, opening and resealing of individual pores was observable even at $P_{r}$ as low as $0.2 \mathrm{MPa}$. The transmembrane current was carried by influx of $\mathrm{Ca}^{2+}$ ions. The transmembrane current was greater at $0.4 \mathrm{MPa}$ than at $0.2 \mathrm{MPa}$; in both cases, pore lifetime was $\sim 2 \mathrm{~s}$. More generally, the effect was $\mathrm{P}_{\mathrm{a}}$ dependent, increasing slowly with increasing $\mathrm{P}_{\mathrm{a}}$ over the range of $0.3-0.55 \mathrm{MPa}$, and then inflecting sharply upward at higher $\mathrm{P}_{\mathrm{a}}$ \{Deng et al. 2004\}. Pore opening showed a high level of temporal correlation with inertial cavitation noise \{Zhou et al. 2008\}. Pore size was estimated as $220 \pm 80$ (mean \pm SD) nanometers, and refined estimates of pore resealing times indicated closure in $3-5 \mathrm{~s}$ \{Zhou et al. 2009\}. In vitro studies of cells in contact with SonoVue MBs excited by $1 \mathrm{MHz}$ US at $\mathrm{P}_{\mathrm{a}}$ of $0.05-2.50 \mathrm{MPa}$ have shown $\mathrm{Ca}^{2+}$ influx associated with poration \{Juffermans et al. 2008\}. Sonoporation to naked DNA in vitro is correlated with inertial cavitation activity \{Qiu et al. 2010\}, and depends in part on the fluidity of the membrane at the time of UTMD treatment \{Zarnitsyn \& Prausnitz 2004\}, with higher reporter gene transfection rates at $37{ }^{\circ} \mathrm{C}$ than at $21{ }^{\circ} \mathrm{C}$. This is consistent with the need for porated membranes to reseal rapidly in order to maintain viability. Still others have shown that $1 \mathrm{MHz}$ US at $\mathrm{P}_{\mathrm{a}}$ as low as $0.1 \mathrm{MPa}$ can permeabilize cells in vitro to pDNA \{Rahim et al. 2006\}. In cell suspensions containing Definity MBs, the $\mathrm{P}_{\mathrm{a}}$ thresholds for cell permeabilization to $70 \mathrm{kDa}$ FITC-dextran, propidium iodide (indicating cell death) and $\mathrm{MB}$ destruction were $75 \mathrm{kPa}$ at $0.5 \mathrm{MHz}, 200 \mathrm{kPa}$ at 2.5 $\mathrm{MHz}$, and $600 \mathrm{kPa}$ at $5 \mathrm{MHz}$ \{Karshafian et al. 2009\}. However, the idea that cellular poration results from inertial cavitation has been challenged on the basis of observations of cavitation noise and permeabilization of in vitro cell monolayers to $500 \mathrm{kDa}$ FITC dextran; the supporting data indicate that permeabilization precedes the occurrence of broadband noise associated with inertial collapse and rebound cavitation. The authors conclude that the forces associated with microstreaming around activated bubbles is the principal mechanism of sonoporation \{Forbes et al. 2008\}. More study is clearly needed.

US and MB-induced cell lysis and reversible poration in other cell types in vitro are strongly correlated with inertial cavitation \{Chen et al. 2003a; Chen et al. 2003b; Lai et al. 2006\}. Cell surface antigens may be stripped off the surface of viable cells during such events \{Brayman et al. 1999\}. While in vitro UTMD-based transfection with naked DNA is often associated with high cell mortality, this is not always the case \{Wang et al. 2009\}.

The use of the collapse jets of MBs generated by laser pulses to selectively and directionally sonoporate individual cells has reached a high level of sophistication, producing pore sizes of $\sim 200 \mathrm{~nm}$ \{Sankin et al. 2010\}, which may someday prove useful for cell therapies. This is very 
similar to pore size determined by sonoporation of Xenopus oocytes using $1.07 \mathrm{MHz}$ US of 0.3 $\mathrm{MPa} \mathrm{P}_{\mathrm{a}}$ with Definity MBs; viz., a mean pore size of $220 \pm 80 \mathrm{~nm}$ diameter \{Zhou Y et al. 2009\}. Lipoplexes, which are normally taken up by cells via endocytosis, are taken up poorly when 'PEGylated' (coated with polyethylene glycol). However, when PEGylated pDNA/lipolexes were attached to acoustically activated MBs, large increases in PEGylated lipoplex transfection were achieved in an in vitro model system, relative to ether 'free' PEGylated lipolexes, or lipolexes + MB simple (un-linked) mixtures \{Lentacker et al. 2009\}. The investigators also used a number of endocytosis inhibitors; their results indicate that endocytosis was not the primary mechanism involved. They postulate that lipoplex-loaded MBs collapsing near cell monolayers in culture plates released the lipolexes, resulting in high local lipoplex concentrations, that some of the released lipolexes became entrained in MB collapse jets and were 'injected' into the cells with the fluid jet (see also \{Miller 2000\}). However, Meijering and colleagues, using fluorescently labeled dextrans of $\sim 4-500 \mathrm{kDa}$, present data which indicate that the principal mechanism by which UTMD treatment (1 $\mathrm{MHz}$ US, $0.2 \mathrm{MPa} \mathrm{P}_{\mathrm{r}}$, SonoVue MBs) facilitates macromolecule delivery across the plasma membrane is via induction of endocytosis. Sonoporation was also observed, but did not seem to be the mechanism for macromolecular uptake \{Meijering et al. 2009\}. It is clear that the our understanding of the mechanism(s) of UTMD-enhanced uptake of macromolecules remains incomplete.

\subsection{Entry of pDNA into the nucleus}

Following delivery of pDNA across the plasma membrane of cells into cytoplasm, pDNA may travel through multiple cellular compartments and finally enter the nucleus via diffusion \{Liang et al. 2004\} or other assisted mechanism to produce efficient transgene expression. UTMD may facilitate overcoming some of these barriers most likely via cavitation bioeffects. It was reported that long-term exposure to therapeutic ultrasound (1 $\mathrm{MHz}, 2 \mathrm{~W} / \mathrm{cm}^{2}, 30 \%$ duty cycle for $30 \mathrm{mins}$ ) can overcome the rate-limiting step of driving DNA into the cell nucleus \{Duvshani-Eshet \& Machluf 2005\}. One thousand fold higher gene expression levels of luciferase was achieved with minimal loss in cell viability $(<20 \%)$ in three different cell types (BHK, LNCaP, and BCE). These data implied that therapeutic US is the main driving force delivering pDNA not only to the cell cytoplasm but also to the nucleus. However, in this case, no MB was used. The same group \{Duvshani-Eshet et al. 2006\} showed that adding Optison further increased transfection levels. Confocal and atomic force microscopy studies indicated that long-term therapeutic US application localizes the pDNA in cell and nucleus regardless of Optison addition. In addition, the use Optison did not affect the kinetics of protein expression, indicating Optison did not affect DNA trafficking to the nucleus. They hypothesized that US application by itself plays a major role in delivering DNA to the nucleus.

An interesting recent report used Doxorubicin (DOX) as a molecular nanotheranostic agent to study UTMD-mediated intracellular delivery and nuclear trafficking \{Mohan \& Rapoport 2010\}. DOX is a popular research tool due to its inherent fluorescence and was encapsulated in poly(ethylene glycol)-co-polycaprolactone (PEG-PCL) micelles or PEG-PCL stabilized perfluorocarbon nanodroplets in this study. US triggered DOX trafficking into cell nuclei; the trafficking was further enhanced in the presence of phase-transition nanodroplets which become gas MBs upon US exposure of sufficient $\mathrm{P}_{\mathrm{r}}$. This was believed to be due to cavitation induced transient permeabilization of both plasma and nuclear membranes, thus 
allowing DOX penetration into the cell nuclei. Whether MBs and/or nanodroplet emulsions can significantly augment DNA delivery to the nucleus needs further investigation.

Once pDNA enters the nucleus, some DNA can be condensed by histones and form persistent nucleosome-like structures. Persistent gene expression from these stable episomal pDNA genomes requires the introduction of specific cis-acting elements in the gene transfer constructs. We have demonstrated that incorporation of locus control region and intron elements into specific gene transfer constructs can achieve persistent expression of therapeutic-levels of coagulation proteins in the liver following nonviral gene therapy \{Miao et al. 2001; Miao et al. 2003; Ye et al. 2003\}. The locus control region \{Yant et al. 2003\} can contribute to the open chromatin structure of the pDNA genome and avoid silencing of the transgene expression cassette \{Miao et al. 2005\}. Furthermore, addition of an intron element significantly enhanced the transcription efficiency of stable mRNA \{Miao et al. 2005\}. Thus, gene transfer of episomal pDNA into slow-dividing or terminally differentiated cells facilitated by UTMD has high potential to achieve a therapeutic effect to treat specific diseases. For gene transfer into dividing cells where integration of target genes are required, incorporation of other systems such as sleeping beauty transposons \{Aronovich et al. 2011; Yant et al. 2007\} or PhiC31 integrase \{Keravala et al. 2011\} with UTMD-mediated nonviral gene transfer methodology can lead to long-term transgene expression.

\section{The vectors: Packaging desired genes for ultrasound-mediated delivery}

\subsection{Naked DNA: Plasmids}

Naked plasmid DNA provides many advantages as a nonviral gene transfer vector, including: (1) ease of preparation, (2) cost-effectiveness, (3) minimum toxicity, and (4) it is least immunogenic of the vectors. Indeed, the immunogenic $\mathrm{CpG}$ moiety can be modified easily if needed. Most importantly, quality control is quite easy compared to other pDNA complexes containing synthetic vehicles. However, it has been a very challenging problem to deliver naked pDNA into specific cells due to its large size and negative charge. In vivo delivery of naked pDNA is especially difficult with additional impediments of instability of pDNA in blood serum as well as in cellular sub-compartments such as cytosol, endosome, and nucleus after cell entry. Recently a hydrodynamic approach has been developed to drive efficient gene delivery into liver \{Liu et al. 1999\} and muscle \{Danko et al. 1997\} resulting in therapeutic levels of transgene expression in animal disease models, including hemophilia B \{Miao et al. 2003\} and others \{Zhang et al. 2000\}. This method in its current form is not suitable for clinical use; however, notable recent advances have been made in large animal models (vide, e.g., \{Fabre et al. 2008; Kamimura et al. 2009; Suda et al. 2008\}. Alternatively, innovative US and MB technology to facilitate delivery of naked pDNA is a potential clinically feasible nonviral gene therapy approach \{Miao et al. 2005; Shen et al. 2008; Song et al. 2011\}.

The potential for sonoporation to increase pDNA loading of cells was recognized years ago \{Fechheimer et al. 1987\}. Sonoporation-enhanced transport of nanoparticles into cells is dependent on molecular size; uptake of particles $\leq 37 \mathrm{~nm}$ diameter was enhanced by sonoporation without gross damage, but particle uptake generally declined as particle size increased \{Mehier-Humbert et al. 2005a\}. pDNA gene expression is faster with sonoporation than with liposome-based methods which depend on endocytosis \{Mehier-Humbert et al. $2005\}$, indicating that pDNA enters cells through transient pores. Moreover, due to the risk of pDNA degradation by serum nucleases and removal by phagocytes [Niidome \& Huang 
$2002\}$, injection of a nonviral gene transfer vector long before US treatment occurs is unlikely to be effective. With simultaneous delivery of pDNA and US exposure, UTMD can significantly facilitate the transfer of naked pDNA up to several hundred fold in vitro \{Miller et al. 2002; Newman \& Bettinger 2007\} and up to several thousand fold in vivo, depending on different US and transfection systems \{Chen et al. 2010; Miao et al. 2005; Shen et al. 2008; Song et al. 2011\}. Furthermore, with introduction of specific cis-acting elements in the gene transfer constructs, persistent expression of near-therapeutic levels of proteins can be achieved from episomal plasmids following UTMD-mediated gene therapy (Miao et al. 2005\}. These results demonstrate that development of UTMD has high potential to achieve a therapeutic effect for treating specific diseases.

\subsection{Encapsulated or compacted DNA}

Polyanionic solutes can be complexed to phospholipid polar head groups via $\mathrm{Ca}^{2+}$ bridges \{Huster et al. 1999\}. Thus, anionic DNA molecules can be compacted onto cationic MB lipid shells. Polylysine has also been used to link naked DNA to phospholipid MB shells \{Wang et al. 2009\}. It appears to be widely believed that enhanced efficiency of gene delivery can be obtained with pDNA in close proximity to MBs and any cell membrane 'defects' they may create, thereby increasing the probability that pDNA will be available to enter through these pores prior to their closure. Thus far, however, there has been inconsistent support for this idea. For example, pDNA coupled electrostatically with cationic MBs were used for local delivery of DNA to vascular muscle cells. One percent of cells were transduced with $40 \%$ of the cells remaining viable Phillips et al. 2010\}. However, reporter plasmid bound to the cationic MB preparation MRX-225 was used to transfect canine myocardium which was exposed to diagnostic US. Reporter gene activity was only observed in the myocardium of those animals that received MB-linked DNA and were exposed to US but not in control untreated animals \{Vannan et al. 2002\}. It is not clear if the pDNA-MB linkage influenced the experimental outcome.

Due to large size of DNA molecules and the concerns of enzymatic degradation of the injected pDNA as well as the low pDNA concentration in the vicinity of sonoporated cell membranes, polymer-coated MBs that can bind and protect the pDNA have been developed for UTMD-mediated gene delivery. Coating albumin-shelled MBs with poly(allylamine hydrochloride) (PAH) makes the surface charge of the MBs positive, but did not affect the size distribution of the MBs. The cationic coating allowed the MBs to bind to $100 \mathrm{fg}$ of pDNA per $\mathrm{MB}$ and protected the bound DNA against nucleases. The PAH coating also significantly increased the lifetime of MBs (half-life $\sim 7 \mathrm{~h}$ ), making them more convenient for in vivo applications \{Lentacker et al. 2006\}.

Another approach to compacting DNA onto MBs is to first incubate the pDNA with a cationic lipid such as GL67 or a cationic polymer such as polyethylenimine (PEI), followed by mixing with MBs. PEI/DNA mixed with SonoVue MBs were injected intravenously in tumor-bearing mice. Following US exposure, reporter gene expression in tumor xenografts was significantly enhanced without causing any apparently adverse effect. Furthermore, with UTMD and PEI complex, vectors carrying a short hairpin RNA (shRNA) targeting human survivin were efficiently delivered into the tumor site, leading to inhibition of surviving gene expression and apoptosis of the tumor cells \{Chen et al. 2010\}.

DNA loading of MB shells can be impressive, but may also be limiting to high yield gene therapies using UTMD. By first forming pDNA-Lipofectamine 2000 complexes, mixing 
these with home-made phospholipid mixtures, agitating under a perflutren atmosphere to generate MBs, and then repeatedly washing the bubbles to remove unassociated DNA, a per bubble loading of $50 \times 10^{-15}$ gram/MB was achieved \{Chen et al. 2006\}. Similar binding rates (approximately $100 \mathrm{fg} / \mathrm{MB}$ ) were reported by others \{Carson et al. 2011\}. Using a layer-bylayer approach, DNA loading of pre-existing cationic MBs was increased 10-fold by first bringing anionic DNA to the surface of the cationic bubble, followed by binding a coating of poly-cationic polylysine to the DNA, followed by more DNA, etc. Loading as high as $~ 2500$ fg DNA/MB was achieved, without apparent impact on the bubbles' dynamical response to acoustic excitation \{Borden et al. 2007\}. However, others have found that in vitro transfection rates are not enhanced by conjugation of reporter pDNA to MB shells \{Tlaxca et al. 2010\}, as found in the in vivo canine myocardium example discussed earlier in this section.

\subsection{Viral vectors}

There have been many reports that US treatment alone, or in combination with MBs, can increase transgene uptake by cells \{Miller et al. 2002; Newman \& Bettinger 2007\}. Even with the difficulty of translating UTMD-mediated results obtained under tissue culture conditions (e.g., infinite media for suspended cells vs. nearby noncompliant boundaries for monolayers) to the fully 3-D, viscoelastic intravascular environment in vivo, in vitro experiments often have the advantage of being better controlled and the results therefore more easily understood. This is not always the case, however. Zheng and colleagues exposed two different endothelial pigment cell lines to adenoviral gene vectors in combination with US or US and MBs $\left(1-3 \mathrm{~W} / \mathrm{cm}^{2} ; \mathrm{P}_{\mathrm{r}}\right.$ appears to have been $\sim 0.17-0.30$ $\mathrm{MPa}$ at $1 \mathrm{MHz}$; SonoVue MBs were used when bubbles were employed). They found that treatment with US and MBs increased adenoviral gene transfer in human retinal pigment epithelium cells, but was without effect on rat retinal pigment epithelial cells under otherwise identical conditions \{Zheng et al. 2009\}. The differences were speculated to arise in consequence to differing ability of the two cell lines to phagocytize the SonoVue MBs, to which the adenoviral vectors were believed to be attached.

It is difficult to limit the specificity of delivery of viral vectors, which are usually delivered systemically. By using retrovirus-loaded MBs, UTMD facilitated the delivery of viral vectors in a restricted area of cells exposed to $\mathrm{P}_{\mathrm{r}}$ of $0.4 \mathrm{MPa}$ or greater, despite uniform dispersion of the vector \{Taylor et al. 2007\}. An envelope-deficient retroviral vector was combined with cationic MBs and added to target cells. Transduction efficiencies and sites can thus be controlled by means of US exposure. These results emphasize that UTMD can not only facilitate the delivery of nonviral vectors, but also has the potential to enhance efficiencies and restrict targeted sites of viral gene transfer.

\subsection{Small RNAs and oligonucleotides}

Small RNAs and oligonucleotides (ODN) have recently been developed as promising therapeutics to treat diseases like viral infections, cancer, and several genetic disorders. Among these, small inhibitory RNA (RNAi or siRNA) based therapeutics have been investigated for treating a number of different diseases, including viral infections (e.g., hepatitis, HIV, influenza), cancer, Huntington's disease, and others. Other therapeutic agents including microRNA (miRNA), transfer RNA (tRNA), and antisense ODN are also being developed to regulate gene or cell functions as treatment regimens. Since these agents are small, it is expected that they will be good candidates for augmented delivery by UTMD. 
The US contrast agent pioneer Thomas Porter recognized early that UTMD delivery of oligonucleotides had the potential to influence vascular tissue remodeling after injury. In a 2001 study, an oligonucleotide which inhibits vascular smooth muscle cell proliferation was bound to albumin-shelled MBs and UTMD effected by transcutaneous application of $20 \mathrm{kHz}$ US to porcine carotid artery walls following balloon catheter injury. Thirty days after treatment, the percent area stenosis in UTMD-treated animals was half that in controls \{Porter et al. 2001\}. The uptake of ODNs into intact ex vivo human saphenous veins and isolated smooth muscle cells from the veins was also potentiated by US \{Kodama et al. 2005\}. In addition, UTMD facilitated the delivery of antisense ODN targeting the human androgen receptor (AR) in prostate tumor cells, resulting in $49 \%$ transfected cells, associated with a decrease in AR expression compared to untreated controls \{Haag et al. 2006\}.

UTMD-mediated sonoporation (frequency: $1 \mathrm{MHz}$; intensity: $2 \mathrm{~W} / \mathrm{cm}^{2}$; exposure time: $2 \mathrm{~min}$ ) was capable of enhancing in vivo siRNA delivery into salivary gland of rats, leading to significant GAPDH gene silencing by $10-50 \%$ for 48 hours \{Sakai et al. 2009\}. No gene silencing was observed with exposure to US only in the absence of Optison MBs. Intraventricular co-injection of siRNA-GFP and MB BR14 with concomitant ultrasonic exposure resulted in a substantial reduction in EGFP expression in the coronary artery in EGFP transgenic mice \{Tsunoda et al. 2005\}. Liposomal MBs combined with US can efficiently delivery siRNA with only 10s of US exposure in vitro. siRNA was also efficiently delivered into the tibialis muscles using the same system and the gene-silencing effect could be sustained for more than 3 weeks \{Negishi et al. 2008\}. These results demonstrate that UTMD-mediated delivery of siRNA can serve as a very useful tool for loss-of-function genetic engineering both in vitro and in vivo.

\subsection{Transduced cell therapy}

Cell therapy is a promising strategy for many applications, including genetic diseases, cancer, regenerative medicine, and others. However, it is very difficult to transfect certain cell types and maintain their viability following transfection, including hematopoietic and mesenchymal stem cells, $\mathrm{T}$ cells, and others which are important targets for cell therapy using the transfection methods currently available. UTMD has been demonstrated to facilitate the delivery of siRNA into mesenchymal stem cells (MSCs) \{Otani et al. 2009\}, which knocked down mRNA expression of specific genes, leading to the improvement of cellular function and viability. The application of UTMD has high potential to facilitate the delivery of genetic materials into target cells and can be expanded for use in a variety of cell therapy protocols.

\section{Selected applications of ultrasound-mediated gene delivery}

\subsection{Cardiovascular}

Recent reviews of cardiac applications of UTMD are provided elsewhere \{Laing \& McPherson 2009; Porter 2009\}. Desired endpoints may be improved vascular function (e.g., following ischemia) or inhibition of vascularization to 'starve' tumors. The following discussion is intended only to provide an indication of some of the exciting avenues of research in the area.

Cardiovascular graft remodeling: Tissue remodeling after transplantation surgery is required for long term transplant success. It has been shown that US-mediated gene therapy can improve transplanted vessel patency after surgery. Carotid interposition saphenous vein 
grafts in pigs were treated ex vivo prior to transplantation with $1 \mathrm{MHz} \mathrm{US}$ at $\sim 1.8 \mathrm{MPa} \mathrm{P}_{\mathrm{a}}$ with both a MB contrast agent and a plasmid encoding for metalloproteinase 3 (TIMP-3; the enzyme inhibits post-graft vessel restriction) present during US exposure. At 4 weeks, luminal diameters in animals receiving the transfected grafts were significantly greater than in controls \{Akowuah et al. 2005\}. Similarly, US treatment enhanced the delivery of an adenoviral vector to the aortic root, yielding a 2.5-fold enhancement in gene delivery (Beeri et al. 2002\}. A technical issue of note is that a balloon catheter was used to briefly occlude the aortic root above the sinuses to increase the dwell time of the injected MBs and adenoviral vectors.

Reperfusion therapies: US-mediated gene therapy to improve myocardial reperfusion following induced myocardial infarcts in mice was studied using Definity MBs, and UTMD achieved using high frequency $\left(8 \mathrm{MHz}\right.$ ), relatively high $\mathrm{P}_{\mathrm{a}}$ (estimated $\sim 4.5 \mathrm{MPa}$ ) US from a diagnostic US machine. Plasmids were either empty (controls) or encoded for Stem Cell Factor (SCF; expected to enhance reperfusion by recruitment of cells during tissue remodeling) or VEGF (expected to stimulate angiogenesis). At 21 days, UTMD with either VEGF or SCF-bearing pDNA increased the microvessel density and blood flow relative to controls \{Fujii et al. 2009\}. Similarly, reperfusion of ischemic rat hind limbs was improved by US-mediated gene therapy. Cationic lipid-shelled MBs and a pDNA encoding for VEGF165 were used; US frequency and amplitude were $1.3 \mathrm{MHz}$ and $\sim 2 \mathrm{MPa}$, respectively \{Kobulnik et al. 2009\}. A murine cardiac infarct model treated with UTMD with pDNA encoding for either VEGF or stem cell factor (SCF) has been reported to increase reperfusion; the observation that SCF-encoding pDNA increased perfusion was interpreted as evidence for the recruitment of reparative cells into the area of infarction \{Fujii et al. 2009\}.

Expression of a reporter plasmid gene delivered to the myocardium by UTMD methods was relatively brief $(4 \mathrm{~d})$, but was improved by retreatment \{Bekeredjian et al. 2003\}. Under similar exposure conditions, damage to the heart was negligible \{Bekeredjian et al. 2004\}. However, UTMD-enhanced gene delivery to the heart is often attended by at least minimal damage, which can include extravasation of large molecules and red cells [Hernot et al. 2010\}. It is noteworthy that under diagnostic US exposure conditions, premature ventricular contractions can occur with the use of US contrast agents (see, e.g. \{Miller et al. 2005\}), and in contrast with the results of $\{$ Hernot et al. 2010\} these have been unambiguously correlated with cell killing of cardiomycetes. In rats, using $1.7 \mathrm{MHz}$ ultrasound, premature complexes and cardiomycete death were observable at $\mathrm{P}_{\mathrm{a}}$ of $2 \mathrm{MPa}$ or greater (Miller et al. 2011\}. Premature contraction complexes appear to be related directly to extravascular cell killing, so even absent gross side effects, some side effects can be expected in gene therapies involving UTMD. This has important implications not only for safety, but also efficacy; i.e., one hopes to transfect the target cells, not kill them. It seems unlikely that transfection to meaningful extents can be achieved without some cell killing, so attempts to optimize UTMD treatments must strive to achieve an acceptable balance between desired effect (transfection) and undesired effect (killing of the target cells).

When treating the heart using reporter genes, MBs and a diagnostic scanner as the acoustic source, superior results were obtained by moving the scan head about to 'paint' a larger volume of tissue \{Geis et al. 2009\}. Another noteworthy finding was that moving the beam relative to the heart did not increase Evans blue dye extravasation, which suggests less microcirculation damage per unit transgene expression when the insonifying beam is moved relative to the target. 
Inhibition of neovascularization: A substantial literature on therapies to inhibit neoangiogenesis exists. Here we mention one recent example: MBs and pDNA encoding for pigment epithelium derived factor, which inhibits neovascularization in the retina, were injected into the vitreous humor of rats having laser-induced choroidal injury, which leads to neovascularization. The eyes were treated immediately with $0.3 \mathrm{MHz}$ US of $\mathrm{P}_{\mathrm{a}}$ estimated to be in the range of $0.1-0.3 \mathrm{MPa}$. At 28 days post treatment, choroidal neovascularization was inhibited in the UTMD group relative to untreated controls \{Zhou XY et al. 2009\}. Similarly, pDNA carrying a silencing sequence for the gene coding for survivin were introduced into implanted murine tumors using UTMD methods. Treated tumors were sonicated with $3 \mathrm{MHz}$ US at an intensity of $2 \mathrm{~W} / \mathrm{cm}^{2}$ (estimated $\mathrm{P}_{\mathrm{r}}$ : $0.2-0.5 \mathrm{MPa}$ ). Transgene expression was significantly increased in tumors treated with UTMB. It was proposed that the technique could be applied therapeutically to tumors to increase in tumor cell apoptosis via the silencing effect on survivin expression in transfected cells [Chen et al. 2010\}.

\subsection{Skeletal muscle}

Among the applications for gene therapy in skeletal muscle is the treatment of muscular dystrophy (see, e.g., \{Alter et al. 2009\} and references therein). As a specific recent example, Kodama and colleagues used various means to attempt delivery of PGL3 luciferase pDNA into murine skeletal muscle. Optison, human albumin MBs or acoustic liposomes (all formulated with $\mathrm{C}_{3} \mathrm{~F}_{8}$ gas) were compared, using a $1 \mathrm{MHz}$ US source; $\mathrm{P}_{\mathrm{a}}$ was $0.2 \mathrm{MPa}$. Treatment with plasmid, US and either Optison or liposomes increased luciferase expression relative to controls. The $\sim 200 \mathrm{~nm}$ diameter acoustic liposomes produced the highest expression rates, presumably because of their very high concentration \{Kodama et al. 2010\}.

\subsection{Pancreas}

Pancreatic gene therapies have focused principally on treatments for diabetes types I and II. The feasibility of using pDNA and UTMD methods to deliver transgenes to the pancreas has been described by Grayburn and colleagues. Following injection of reporter gene pDNA attached to the MB phospholipid shells, the reporter gene was expressed with fairly high spatial specificity, declining after 4 days, but with measurable expression persisting for as long as 21 days (\{Chen et al. 2006\}; see internal citations for a discussion of viral approaches). US of $\sim 3 \mathrm{MHz}$ was used, with an apparent $\mathrm{Pa}_{\mathrm{a}}$ of $\sim 1 \mathrm{MPa}$ at the pancreas. When plasmid vectors carrying human insulin and hexokinase I gene were delivered using UTMD, transgene expression was obtained in islets and decreased circulating glucose levels were observed in treated rats. These data indicate that UTMD allows relatively noninvasive delivery of genes to pancreatic islets to modulate beta cell function. More recently, the same group reported that delivery of NeuroD1 gene driven by a rat insulin promoter (RAP3.1) into rats by UTMD-mediated gene delivery targeting pancreas in vivo promoted islet regeneration from surviving beta-cells, with normalization of glucose, insulin and C-peptide levels at 30 days $\{$ Chen et al. 2010\}.

\subsection{Liver}

Liver is a major organ for protein synthesis, and therefore represents an important target for gene therapy. We will discuss here UTMD-mediated gene therapy targeting liver for treating non-tumoral diseases. 
Our group has extensively studied gene delivery of reporter and therapeutic genes into the liver. We have demonstrated that UTMD (1 MHz US) can significantly enhance gene transfer of naked pDNA into the mouse liver in the presence of either Optison \{Miao 2005\} or Definity MBs \{Shen et al. 2008\}. Transgene expression was dependent exponentially on $\mathrm{P}_{\mathrm{r}}$, with an inflection point usually between 1 and $2.5 \mathrm{MPa}$ followed by a plateau above 3 $\mathrm{MPa}$ \{Song et al. 2011a\}, consistent with an inertial cavitation mechanism. More than thousand-fold enhancement of gene transfer efficiencies was obtained compared to control experiments in the absence of UTMD. Recently we have gained preliminary success in scaling up pDNA delivery in larger animal models, including rats \{Song et al. 2011b \} and dogs \{Noble et al. 2011\}. Previously we have shown that near therapeutic levels of factor IX were achieved by UTMD-mediated gene delivery in mice. Technical improvements to further enhance gene transfer of factor VIII for treatment of hemophilia A and factor IX for treatment of hemophilia B are currently being pursued in small and large animal models.

\subsection{Kidney}

A number of kidney diseases could be potentially treated with gene therapies. Hydrodynamic approaches have met with some success. Xing et al. attempted to improve on these results by combining hydrodynamic and UTMD approaches to naked DNA reporter gene delivery to surgically-exposed rat kidneys. Combined US (unspecified frequency) from a Sonotron 2000 hand-held diagnostic US machine and hydrodynamic therapy together yielded better reporter gene transfection than hydrodynamic therapy alone, producing an approximately 4 -fold increase in reported gene expression when the estimated $\mathrm{P}_{\mathrm{a}}$ was in the range of $0.3-0.8 \mathrm{MPa}$ and no MBs were used. The effect was intensity-dependent. When Optison MBs were injected with the naked DNA during hydrodynamic therapy and US exposure, the same effect (4-fold increase in gene expression) was observed at an intensity of only $1 \mathrm{Watt} / \mathrm{cm}^{2}$ (estimated $0.2-0.5 \mathrm{MPa} \mathrm{P}_{\mathrm{a}}$ ) \{Xing et al. 2009\}.

\subsection{Skin (DNA vaccine)}

The failure of wounds to heal in diabetic patients is a significant clinical problem. Gene therapies which promote angiogenesis represent a promising approach to this problem. VEGF-encoding gene vectors (either minicircle naked DNA; a supercoiled form with a molecular weight estimated as $331 \mathrm{~g} / \mathrm{mol}$, or naked DNA borne on the gene carrier branched polyethylinimine) were tested for efficacy in inducing circulating VEGF expression and accelerating wound healing in an induced diabetic mouse model. Wounds were treated by peripheral injection of gene vectors with or without exposure to US ( $1 \mathrm{MHz}$, $2 \mathrm{~W} / \mathrm{cm}^{2}, 20 \%$ duty cycle; estimated $0.25-0.5 \mathrm{MPa}$ ). In some treatments, SonoVue MBs were injected with the microcircle DNA prior to sonication. Markedly greater levels of circulating VEGF were observed in mice treated with [VEGF-encoding minicircle DNA + US + MBs] relative to controls, but not as high as those obtained using the polyethylinimine gene carrier. Nonetheless, the [minicircle DNA + US + MBs] treatment produced a significant improvement in healing rates of the treated skin wounds \{Yoon et al. 2009\}.

\subsection{Other solid organs}

Brain: Much work has been done on 'opening' (i.e., making more permeable) the bloodbrain barrier, which so tightly regulates traffic between the vascular space and the brain that chemotherapeutic agents often cannot cross the barrier \{Meairs \& Alonso 2007\}. Much 
success with tracer molecules (e.g., Evans blue dye, gadolinium MRI contrast agents, etc.) has been achieved using UTMD methods, principally in small animal models. However, low energy US applied through the temporal bone of swine produced short-term permeabilization of the blood-brain barrier with exogenous MBs (see \{Xie et al. 2008\} and citations within). However, we have found no reports of UTMD gene therapies attempted in the brain.

\subsection{Endothelium}

There are many papers which indicate that endothelial cells in vitro can express transgenes delivered by UTMD methods (see $\{\mathrm{Su}$ et al. 2010\} and internal references for recent examples). Su and colleagues found that treatment with $1 \mathrm{MHz}$ US of $1 \mathrm{MPa} \mathrm{P}_{\mathrm{r}}$ together with pGL3 pDNA and MBs yielded a 100-fold increase in luciferase expression relative to pDNA treatment alone. It remains to be determined if endothelial cells in vivo can be 'recruited' as effective synthesizers and secretors of therapeutic gene expression products.

\subsection{Cell therapies: Ex vivo gene therapy}

In this section, we discuss several examples of US-mediated gene delivery using cell cultures in vitro; these may have some mechanistic relevance to the in vivo condition. However, some of the results obtained using in vitro cells may have direct bearing on cell therapies.

Shock waves and MBs have been used in vitro to increase pDNA uptake in cultured HEK cells; the technique worked, but was associated with substantial cell killing \{Bekeredjian et al. 2007\} as might be expected (see, e.g., \{Brayman et al. 1999; Hwang et al. 2006; Hwang et al. 2003\}). As a general rule, only a small fraction $(\sim 5-10 \%)$ of cells insonated with MBs in vitro undergo transient poration; these yields are often associated with cell killing rates of $\sim 50 \%$ (see, e.g. \{AIUM 2000; AIUM 2008\} and references therein). If those cells can be sorted (e.g., by flow cytometry) and cultured to increase cell numbers, this may be acceptable for cell therapies - if the gene vector is integrated into the host genome. An obvious problem for cell therapies based on this approach with naked DNA, however, is that the pDNA does not replicate with the host cell, and so there would be little to be gained by increasing cell numbers of the transfected subpopulation of cells. However, using suspended KHT-C cells, and $3 \mathrm{~V} \%$ Definity, high levels of in vitro permeabilization to $70 \mathrm{kDa}$ fluorescein isothiocyanate (FITC) dextran were achieved using $0.5 \mathrm{MHz}$ US at a $\mathrm{P}_{\mathrm{a}}$ of $0.57 \mathrm{MPa}, 16$ cycle pulses repeated at 3 $\mathrm{kHz}$ PRF. About $30 \%$ of the cells were permeabilized, with $>95 \%$ retention of viability \{Karshafian et al. 2009\}. If similar results can be obtained with naked DNA, the prospects for cell therapies using cells transfected using in vitro UTMD seem much brighter.

\subsection{Gene therapies for tumoricidal activity}

Strategies currently under investigation for treatment of cancers include anti-angiogenic therapies, the introduction of 'suicide genes' which either induce apoptosis or sensitize cells to subsequent treatment with drugs \{Aoi et al. 2008; Azuma et al. 2008; Daigeler et al. 2010; Kirn et al. 2002; Zhou et al. 2010\}, or down-regulate oncogenes \{Wang et al. 2009\}. Naked DNA bearing the Herpes-derived 'suicide gene' for thymidine kinase has been delivered to murine squamous cell carcinomas by UTMD methods $\left(1.3 \mathrm{MHz}\right.$, estimated $\left.\mathrm{P}_{\mathrm{r}} \sim 1.8 \mathrm{MPa}\right)$. The DNA was bound to lipid shelled MBs at a rate of about $100 \mathrm{fg}$ DNA/MB. With daily ganciclovir treatments beginning $3 \mathrm{~d}$ after UTMD and pDNA treatment, tumor doubling times were significantly reduced (by $\sim 17 \%$ ) in the UTMD-treated tumors \{Carson et al. 2011\}. 
In tumors as in other systems, extravasation of gene vectors seems to be a constraint for delivery of antitumoral therapeutics which are delivered intravascularly. Here, too, UTMD appears to aid in increasing vascular permeability. For example, in implanted subcutaneous hepatomas, extravasation of Evans blue dye was 5-fold higher in the UTMD and plasmidtreated tumors than in untreated control tumors; there was no increase in Evans blue extravasation when US was applied without MBs. In this case, however, there was no significant transfection by the pDNA \{Bekeredjian et al. 2007\}. UTMD techniques have been used successfully to introduce the gene for tumor suppression protein p53 into murine retinoblastoma xenografts; when insonated in the presence of MBs or liposomes, significant expression of p53 resulted; there was no expression in the plasmid-only or plasmid + US groups \{Luo et al. 2010\}.

\section{Concluding remarks}

Much exciting work on ultrasound-mediated gene delivery has already been done, but the field remains young and even preclinical applications involving therapeutic genes are relatively few. A few generalities may be put forth: In most (but not all) cases, ultrasoundmediated gene delivery is dependent on, or greatly facilitated by, exogenous microbubbles. Where this is the case, the acoustic exposures are usually such that the bubbles can be expected to behave in a nonlinear way. Given the intense effort being devoted to the topic, we can anticipate with some confidence that successful gene therapies in large animals and early human trials will be achieved in the near future.

\section{Acknowledgements}

The authors acknowledge gratefully the support of NIH grants 5R01HL069049 (C.H.M., A.A.B), 5R21/R33HL089038 (C.H.M., A.A.B); 5R01HL082600 (C.H.M.); 1R01CA917794 (A.A.B.), and 1RO1CA109557 (A.A.B.), 5RO1EB000350 (A.A.B.) and Bayer Hemophilia Award (C.H.M.). We thank Drs. Thomas J. Matula, Wayne Kreider, Michael R. Bailey, Peter J. Kaczkowski, Mark Borden, Misty Noble, Sophia Song and Ms. Hong Chen for helpful discussions during preparation of this manuscript.

\section{References}

AIUM. (2000) Mechanical Bioeffects from Diagnostic Ultrasound: AIUM Consensus Statements. Section 6 - Mechanical bioeffects in the presence of gas-carrier ultrasound contrast agents. J Ultrasound Med 19: 120 - 142.

AIUM. (2008) American Institute of Ultrasound in Medicine Consensus Report on Potential Bioeffects of Diagnostic Ultrasound: Executive Summary. J Ultrasound Med 27: 503515.

Akowuah EF, Gray C, Lawrie A, Sheridan PJ, Su CH, Bettinger T, Brisken AF, Gunn J, Crossman DC, Francis SE, Baker AH, Newman CM. (2005) Ultrasound-mediated delivery of TIMP-3 plasmid DNA into saphenous vein leads to increased lumen size in a porcine interposition graft model. Gene Ther 12: 1154-1157.

Alter J, Sennoga CA, Lopes DM, Eckersley RJ, Wells DJ. (2009) Microbubble stability is a major determinant of the efficiency of ultrasound and microbubble mediated in vivo gene transfer. Ultrasound Med Biol 35: 976-984. 
Aoi A, Watanabe Y, Mori S, Takahashi M, Vassaux G, Kodama T. (2008) Herpes simplex virus thymidine kinase-mediated suicide gene therapy using nano/microbubbles and ultrasound. Ultrasound Med Biol 34: 425-434.

Apfel RE, Holland CK. (1991) Gauging the likelihood of cavitation from short-pulse, low duty cycle diagnostic ultrasound. Ultrasound Med Biol 17: 179 - 185.

Aronovich EL, McIvor RS, Hackett PB. (2011) The Sleeping Beauty transposon system - a non-viral vector for gene therapy. Human Molec Genetics Epub ahead of print.

Azuma H, Tomita N, Sakamoto T, Kiyama S, Inamoto T, Takahara K, Kotake Y, Segawa N, Morishita R, Takahara S, Hayasaki H, Otsuki Y, Horie S, Tanigawa N, Katsuoka Y. (2008) Marked regression of liver metastasis by combined therapy of ultrasound-mediated NF kappaB-decoy transfer and transportal injection of paclitaxel, in mouse. Int J Cancer 122: 1645-1656.

Beeri R, Guerrero JL, Supple G, Sullivan S, Levine RA, Hajjar RJ. (2002) New efficient catheter-based system for myocardial gene delivery. Circulation 106: 1756-1759.

Bekeredjian R, Bohris C, Hansen A, Katus HA, Kuecherer HF, Hardt SE. (2007) Impact of microbubbles on shock wave-mediated DNA uptake in cells in vitro. Ultrasound Med Biol 33: 743-750.

Bekeredjian R, Chen S, Frenkel PA, Grayburn PA, Shohet RV. (2003) Ultrasound-targeted microbubble destruction can repeatedly direct highly specific plasmid expression to the heart. Circulation 108: 1022-1026.

Bekeredjian R, Chen S, Pan W, Grayburn PA, Shohet RV. (2004) Effects of ultrasoundtargeted microbubble destruction on cardiac gene expression. Ultrasound Med Biol 30: 539-543.

Bekeredjian R, Kroll RD, Fein E, Tinkov S, Coester C, Winter G, Katus HA, Kulaksiz H. (2007) Ultrasound targeted microbubble destruction increases capillary permeability in hepatomas. Ultrasound Med Biol 33: 1592-1598.

Blake JR, Gibson DC. (1987) Cavitation bubbles near boundaries. Ann Rev Fluid Mechanics 19: $99-123$.

Borden MA, Caskey CF, Little E, Gillies RJ, Ferrara KW. (2007) DNA and polylysine adsorption and multilayer construction onto cationic lipid-coated microbubbles. Langmuir 23: 9401-9408.

Borden MA, Kruse DE, Caskey CF, Zhao S, Dayton PA, Ferrara KW. (2005) Influence of lipid shell physicochemical properties on ultrasound-induced microbubble destruction. IEEE Trans UFFC 52: 992-2002.

Brayman AA, Coppage ML, Vaidya S, Miller MW. (1999) Transient poration and cell surface receptor removal from human lymphocytes in vitro by $1 \mathrm{MHz}$ ultrasound. Ultrasound Med Biol 25: 999-1008.

Carson AR, McTiernan CF, Lavery L, Hodnick A, Grata M, Leng X, Wang J, Chen X, Modzelewski RA, Villanueva FS. (2011) Gene therapy of carcinoma using ultrasound-targeted microbubble destruction. Ultrasound Med Biol 37: 393-402.

Carstensen EL, Gracewski S, Dalecki D. (2000) The search for cavitation in vivo. Ultrasound Med Biol 26: 1377-1385.

Caskey CF, Stieger SM, Qin S, Dayton PA, Ferrara KW. (2007) Direct observations of ultrasound microbubble contrast agent interaction with the microvessel wall. $J$ Acoust Soc America 122: 1191-1200. 
Chahine GL. (1977) Interaction between an oscillating bubble and a free-surface. J Fluid EngT ASME 99: 709-716.

Chen H, Brayman AA, Bailey MR, Matula TJ. (2010) Blood vessel rupture by cavitation. Urological Res 38: 321-326.

Chen H, Kreider W, Brayman AA, Bailey MR, Matula TJ. (2011) Blood vessel deformations on microsecond time scales by ultrasonic cavitation. Phys Review Lett 106: 034301034304.

Chen S, Ding JH, Bekeredjian R, Yang BZ, Shohet RV, Johnston SA, Hohmeier HE, Newgard CB, Grayburn PA. (2006) Efficient gene delivery to pancreatic islets with ultrasonic microbubble destruction technology. Proc Nat Acad Sci USA 103: 84698474.

Chen S, Shimoda M, Wang MY, Ding J, Noguchi H, Matsumoto S, Grayburn PA. (2010) Regeneration of pancreatic islets in vivo by ultrasound-targeted gene therapy. Gene Ther 17: 1411-1420.

Chen W-S, Matula TJ, Brayman AA, Crum LA. (2003) A comparison of the fragmentation thresholds and inertial cavitation doses of different ultrasound contrast agents. $J$ Acoust Soc America 113: 643 - 651.

Chen WS, Brayman AA, Matula TJ, Crum LA. (2003a) Inertial cavitation dose and hemolysis produced in vitro with or without Optison. Ultrasound Med Biol 29: 725737.

Chen WS, Brayman AA, Matula TJ, Crum LA, Miller MW. (2003b) The pulse lengthdependence of inertial cavitation dose and hemolysis. Ultrasound Med Biol 29: 739748.

Chen ZY, Liang K, Qiu RX. (2010) Targeted gene delivery in tumor xenografts by the combination of ultrasound-targeted microbubble destruction and polyethylenimine to inhibit survivin gene expression and induce apoptosis. J Exp Clin Cancer Res 29: 152.

Chomas JE, Dayton P, Allen J, Morgan K, Ferrara KW. (2001) Mechanisms of contrast agent destruction. IEEE Trans UFFC 48: 232-248.

Chomas JE, Dayton P, Ferarra K. (2001) Threshold of fragmentation for ultrasonic contrast agents. J Biomedical Optics 6: 141 - 159.

Church CC, Carstensen EL. (2001) "Stable" inertial cavitation. Ultrasound Med Biol 27: 1435 1437.

Cosgrove D, Harvey C. (2009) Clinical uses of microbubbles in diagnosis and treatment. Medical and Biological Engineering and Computing 47: 813-826.

Daigeler A, Chromik AM, Haendschke K, Emmelmann S, Siepmann M, Hensel K, Schmitz G, Klein-Hitpass L, Steinau HU, Lehnhardt M, Hauser J. (2010) Synergistic effects of sonoporation and taurolidin/TRAIL on apoptosis in human fibrosarcoma. Ultrasound Med Biol 36: 1893-1906.

Danko I, Williams P, Herweijer H, Zhang G, Latendresse JS, Bock I, Wolff JA. (1997) High expression of naked plasmid DNA in muscles of young rodents. Human Molec Genetics 6: 1435-1443.

de Jong N, Emmer M, van Wamel A, Versluis M. (2009) Ultrasonic characterization of ultrasound contrast agents. Medical and Biological Engineering and Computing 47: 861-873. 
Deng CX, Sieling F, Pan H, Cui J. (2004) Ultrasound-induced cell membrane porosity. Ultrasound Med Biol 30: 519-526.

Doinikov AA, Bouakaz A. (2010) Theoretical investigation of shear stress generated by a contrast microbubble on the cell membrane as a mechanism for sonoporation. $J$ Acoust Soc America 128: 11-19.

Duvshani-Eshet M, Baruch L, Kesselman E, Shimoni E, Machluf M. (2006) Therapeutic ultrasound-mediated DNA to cell and nucleus: bioeffects revealed by confocal and atomic force microscopy. Gene Ther 13: 163-172.

Duvshani-Eshet M, Machluf M. (2005) Therapeutic ultrasound optimization for gene delivery: a key factor achieving nuclear DNA localization. J Controlled Release 108: 513-528.

Emmer M, van Wamel A, Goertz DE, de Jong N. (2007) The onset of microbubble vibration. Ultrasound Med Biol 33: 941-949.

Fabre JW, Grehan A, Whitehorne M, Sawyer GJ, Dong X, Salehi S, Eckley L, Zhang X, Seddon M, Shah AM, Davenport M, Rela M. (2008) Hydrodynamic gene delivery to the pig liver via an isolated segment of the inferior vena cava. Gene Ther 15: 452462.

Fechheimer M, Boylan JF, Parker S, Sisken JE, Patel GL, Zimmer SG. (1987) Transfection of mammalian cells with plasmid DNA by scrape loading and sonication loading. Proc Nat Acad Sci USA 84: 8463-8467.

Ferrara KW. (2008) Driving delivery vehicles with ultrasound. Adv Drug Deliv Rev 60: 10971102.

Ferrara KW, Borden MA, Zhang H. (2009) Lipid-shelled vehicles: engineering for ultrasound molecular imaging and drug delivery. Accounts Chem Res 42: 881-892.

Fischer K, Gedroyc W, Jolesz FA. (2010) Focused ultrasound as a local therapy for liver cancer. Cancer J 16: 118-124.

Forbes MM, Steinberg RL, O'Brien WD, Jr. (2008) Examination of inertial cavitation of Optison in producing sonoporation of Chinese hamster ovary cells. Ultrasound Med Biol 34: 2009-2018.

Fujii H, Sun Z, Li SH, Wu J, Fazel S, Weisel RD, Rakowski H, Lindner J, Li RK. (2009) Ultrasound-targeted gene delivery induces angiogenesis after a myocardial infarction in mice. JACC Cardiovascular Imaging 2: 869-879.

Geis NA, Mayer CR, Kroll RD, Hardt SE, Katus HA, Bekeredjian R. (2009) Spatial distribution of ultrasound targeted microbubble destruction increases cardiac transgene expression but not capillary permeability. Ultrasound Med Biol 35: 11191126.

Gross DR, Miller DL, Williams AR. (1985) A search for ultrasonic cavitation within the canine cardiovascular system. Ultrasound Med Biol 11: 85-97.

Haag P, Frauscher F, Gradl J, Seitz A, Schafer G, Lindner JR, Klibanov AL, Bartsch G, Klocker H, Eder IE. (2006) Microbubble-enhanced ultrasound to deliver an antisense oligodeoxynucleotide targeting the human androgen receptor into prostate tumours. J Steroid Biochem and Molec Biol 102: 103-113.

Hacein-Bey-Abina S, Le Deist F, Carlier F, Bouneaud C, Hue C, De Villartay JP, Thrasher AJ, Wulffraat N, Sorensen R, Dupuis-Girod S, Fischer A, Davies EG, Kuis W, Leiva L, Cavazzana-Calvo M. (2002) Sustained correction of X-linked severe 
combined immunodeficiency by ex vivo gene therapy. New England J Med 346: 1185-1193.

Hacein-Bey-Abina S, von Kalle C, Schmidt M, Le Deist F, Wulffraat N, McIntyre E, Radford I, Villeval JL, Fraser CC, Cavazzana-Calvo M, Fischer A. (2003) A serious adverse event after successful gene therapy for X-linked severe combined immunodeficiency. New England J Med 2003; 348: 255-256.

Hall TL, Hempel CR, Wojno K, Xu Z, Cain CA, Roberts WW. (2009) Histotripsy of the prostate: dose effects in a chronic canine model. Urology 74: 932-937.

Han YW, Ikegami A, Chung P, Zhang L, Deng CX. (2007) Sonoporation is an efficient tool for intracellular fluorescent dextran delivery and one-step double-crossover mutant construction in Fusobacterium nucleatum. Appl Environ Microbiol 73: 3677-3683.

Hernot S, Cosyns B, Droogmans S, Garbar C, Couck P, Vanhove C, Caveliers V, van Camp G, Bossuyt A, LaHoutte T. (2010) Effect of high-intensity ultrasoundtargeted microbubble destruction of perfusion and function of the rat heart assessed by pinhole-gated SPECT. Ultrasound Med Biol 36: 158 - 165.

Horie S, Watanabe Y, Chen R, Mori S, Matsumura Y, Kodama T. (2010) Development of localized gene delivery using dual intensity ultrasound in the bladder. Ultrasound Med Biol 36: 1867 - 1875.

Huang SL. (2008) Liposomes in ultrasonic drug and gene delivery. Adv Drug Deliv Rev 60: 1167-1176.

Huster D, Paasche G, Dietrich U, Zschornig O, Gutberlet T, Gawrisch K, Arnold K. (1999) Investigation of phospholipid area compression induced by calcium-mediated dextran sulfate interaction. Biophys J 77: 879-887.

Hwang JH, Brayman AA, Reidy MA, Matula TJ, Kimmey MB, Crum LA. (2005) Vascular effects induced by combined $1-\mathrm{MHz}$ ultrasound and microbubble contrast agent treatments in vivo. Ultrasound Med Biol 31: 553-564.

Hwang JH, Tu J, Brayman AA, Matula TJ, Crum LA. (2006) Correlation between inertial cavitation dose and endothelial cell damage in vivo. Ultrasound Med Biol 32: 16111619.

Hwang JH, Vaezy S, Martin RW, Cho MY, Noble ML, Crum LA, Kimmey MB. (2003) High-intensity focused US: a potential new treatment for GI bleeding. Gastrointest Endosc 58: 111-115.

Juffermans LJ, Kamp O, Dijkmans PA, Visser CA, Musters RJ. (2008) Low-intensity ultrasound-exposed microbubbles provoke local hyperpolarization of the cell membrane via activation of $\mathrm{BK}(\mathrm{Ca})$ channels. Ultrasound Med Biol 34: 502-508.

Juffermans LJ, van Dijk A, Jongenelen CAM, Drukarch B, Reijerkerk AR, de Vries HE, Kamp O, Musters RJ. (2009) Ultrasound and microbubble-induced intra- and intercellular bioeffects in primary endothelial cells. Ultrasound Med Biol 35: 1917 1927.

Kamimura K, Suda T, Xu W, Zhang G, Liu D. (2009) Image-guided, lobe-specific hydrodynamic gene delivery to swine liver. Molecular Ther 17: 491-499.

Karshafian R, Bevan PD, Williams R, Samac S, Burns PN. (2009) Sonoporation by ultrasound-activated microbubble contrast agents: Effect of acoustic exposure parameters on cell membrane permeability and cell viability. Ultrasound Med Biol 35: 847 - 860 . 
Kay MA, Manno CS, Ragni MV, Larson PJ, Couto LB, McClelland A, Glader B, Chew AJ, Tai SJ, Herzog RW, Arruda V, Johnson F, Scallan C, Skarsgard E, Flake AW, High KA. (2000) Evidence for gene transfer and expression of factor IX in haemophilia B patients treated with an AAV vector. Nature Genetics 224: 257-261.

Kaya M, Gregory V TS, Dayton PA. (2009) Changes in lipid-encapsulated microbubble population during continuous infusion and methods to maintain consistency. Ultrasound Med Biol 35: 1748 - 1755.

Keravala A, Chavez CL, Hu G, Woodard LE, Monahan PE, Calos MP. (2011) Long-term phenotypic correction in factor IX knockout mice by using phiC31 integrasemediated gene therapy. Gene Ther Epub ahead of print.

Kirn D, Niculescu-Duvaz I, Hallden G, Springer CJ. (2002) The emerging fields of suicide gene therapy and virotherapy. Trends Molec Sci 8: S68-73.

Kobulnik J, Kuliszewski MA, Stewart DJ, Lindner JR, Leong-Poi H. (2009) Comparison of gene delivery techniques for therapeutic angiogenesis: ultrasound-mediated destruction of carrier microbubbles versus direct intramuscular injection. J Am Coll Cardiol 54: 1735-1742.

Kodama T, Aoi A, Watanabe Y, Horie S, Kodama M, Li L, Chen R, Teramoto N, Morikawa H, Mori S, Fukumoto M. (2010) Evaluation of transfection efficiency in skeletal muscle using nano/microbubbles and ultrasound. Ultrasound Med Biol 36: $1196-1205$.

Kodama T, Tan PH, Offiah I, Partridge T, Cook T, George AJ, Blomley MJ. (2005) Delivery of oligodeoxynucleotides into human saphenous veins and the adjunct effect of ultrasound and microbubbles. Ultrasound Med Biol 31: 1683-1691.

Kodama T, Tomita Y. (2000) Cavitation bubble behavior and bubble-shock wave interaction near a gelatin surface as a study of in vivo bubble dynamics. Appl Phys B-Lasers 70: 139-149.

Krupka TM, Solorio L, Wilson RE, Wu H, Azar N, Exner AA. (2009) Formulation and characterization of echogenic lipid-Pluronic nanobubbles. Mol Pharm 7: 49-59.

Lai CY, Wu CH, Chen CC, Li PC. (2006) Quantitative relations of acoustic inertial cavitation with sonoporation and cell viability. Ultrasound Med Biol 32: 1931-1941.

Laing ST, McPherson DD. (2009) Cardiovascular therapeutic uses of targeted ultrasound contrast agents. Cardiovascular Res 83: 626 - 634.

Lentacker I, De Geest BG, Vandenbroucke RE, Peeters L, Demeester J, De Smedt SC, Sanders NN. (2006) Ultrasound-responsive polymer-coated microbubbles that bind and protect DNA. Langmuir 22: 7273-7278.

Lentacker I, Wang N, Vandenbroucke RE, Demeester J, De Smedt SC, Sanders NN. (2009) Ultrasound exposure of lipoplex loaded microbubbles facilitates direct cytoplasmic entry of the lipoplexes. Mol Pharmaceutics 6: 457 - 467.

Li P, Armstrong WF, Miller DL. (2004) Impact of myocardial contrast echocardiography on vascular permeability: comparison of three different contrast agents. Ultrasound Med Biol 30: 83-91.

Liang HD, Lu QL, Xue SA, Halliwell M, Kodama T, Cosgrove DO, Stauss HJ, Partridge TA, Blomley MJ. (2004) Optimisation of ultrasound-mediated gene transfer (sonoporation) in skeletal muscle cells. Ultrasound Med Biol 30: 1523-1529.

Lindner JR. (2009) Contrast ultrasound molecular imaging: harnessing the power of bubbles. Cardiovascular Res 83: 615-616. 
Liu F, Song Y, Liu D. (1999) Hydrodynamics-based transfection in animals by systemic administration of plasmid DNA. Gene Ther 6: 1258-1266.

Luo J, Zhou X, Diao L, Wang Z. (2010) Experimental research on wild-type p53 plasmid transfected into retinoblastoma cells and tissues using an ultrasound microbubble intensifier. J Int Med Res 38: 1005-1015.

Manno CS, Pierce GF, Arruda VR, Glader B, Ragni M, Rasko JJ, Ozelo MC, Hoots K, Blatt P, Konkle B, Dake M, Kaye R, Razavi M, Zajko A, Zehnder J, Rustagi PK, Nakai H, Chew A, Leonard D, Wright JF, Lessard RR, Sommer JM, Tigges M, Sabatino D, Luk A, Jiang H, Mingozzi F, Couto L, Ertl HC, High KA, Kay MA. (2006) Successful transduction of liver in hemophilia by AAV-Factor IX and limitations imposed by the host immune response. Nature Med 12: 342-347.

Marmottant P, de Jong N, Hilgenfeldt S, Lohse D. (2005) A model for large amplitude oscillations of coated bubbles accounting for buckling and rupture. J Acoust Soc America 118: 3499 - 3505.

Maruvada S, Hynynen K. (2004) Optical monitoring of ultrasound-induced bioeffects in glass catfish. Ultrasound Med Biol 30: 67-74.

Matula TJ. (2003) Bubble levitation and translation under single-bubble sonoluminescence conditions. J Acoust Soc America 114: 775-781.

Meairs S, Alonso A. (2007) Ultrasound, microbubbles and the blood-brain barrier. Prog Biophys Mol Biol 93: 354-362.

Mehier-Humbert S, Bettinger T, Yan F, Guy RH. (2005) Plasma membrane poration induced by ultrasound exposure: implication for drug delivery. J Control Release 104: 213-222.

Meijering BD, Juffermans LJ, van Wamel A, Henning RH, Zuhorn IS, Emmer M, Versteilen AM, Paulus WJ, van Gilst WH, Kooiman K, de Jong N, Musters RJ, Deelman LE, Kamp O. (2009) Ultrasound and microbubble-targeted delivery of macromolecules is regulated by induction of endocytosis and pore formation. Circ Res 104: 679-687.

Miao CH. (2005) A novel gene expression system: non-viral gene transfer for hemophilia as model systems. Adv Genetics 54: 143 - 177.

Miao CH, Brayman AA, Loeb KR, Ye P, Zhou L, Mourad P, Crum LA. (2005) Ultrasound enhances gene delivery of human factor IX plasmid. Human Gene Ther 16: 893-905.

Miao CH, Thompson AR, Loeb K, Ye X. (2001) Long-term and therapeutic-level hepatic gene expression of human factor IX after naked plasmid transfer in vivo. Molecular Therapy 3: 947-957.

Miao CH, Ye X, Thompson AR. (2003) High-level factor VIII gene expression in vivo achieved by nonviral liver-specific gene therapy vectors. Human Gene Ther 14: 12971305.

Miao H, Gracewski SM, Dalecki D. (2008) Ultrasonic excitation of a bubble inside a deformable tube: implications for ultrasonically induced hemorrhage. J Acoust Soc America 124: 2374-2384.

Miller D, Li P, Armstrong WF. (2004) The effect of time and of vasoactive drugs on capillary leakage induced during myocardial contrast echocardiography. Echocardiography 21: $125-132$. 
Miller DL, Dou C, Wiggins RC. (2009) Glomerular capillary hemorrhage induced in rats by diagnostic ultrasound with gas-body contrast agent produces intratubular obstruction. Ultrasound Med Biol 35: 869-877.

Miller DL, Dou C, Wiggins RC. (2010a) Contrast-enhanced diagnostic ultrasound causes renal tissue damage in a porcine model. J Ultrasound Med 29: 1391-1401.

Miller DL, Dou C, Wiggins RC. (2010b) In vivo gas body efficacy for glomerular capillary hemorrhage induced by diagnostic ultrasound in rats. IEEE Trans Biomed Eng 57: 167-174.

Miller DL, Dou C, Wiggins RC, Wharram BL, Goyal M, Williams AR. (2007) An in vivo rat model simulating imaging of human kidney by diagnostic ultrasound with gasbody contrast agent. Ultrasound Med Biol 33: 129-135.

Miller DL, Dou H, Lucchesi BR. (2011) Are ECG premature complexes induced by ultrasonic cavitation electrophysiological responses to irreversible cardiomycete injury? Ultrasound Med Biol 37: 312 - 320.

Miller DL, Driscoll EM, Dou C, Armstrong WF, Lucchesi BR. (2006) Microvascular permeabilization and cardiomyocyte injury provoked by myocardial contrast echocardiography in a canine model. J Am Coll Cardiol 47: 1464-1468.

Miller DL, Gies RA. (1998a) Gas-body-based contrast agent enhances vascular bioeffects of $1.09 \mathrm{MHz}$ ultrasound on mouse intestine. Ultrasound Med Biol 24: 1201-1208.

Miller DL, Gies RA. (1998b) The interaction of ultrasonic heating and cavitation in vascular bioeffects on mouse intestine. Ultrasound Med Biol 24: 123-128.

Miller DL, Gies RA. (2000) The influence of ultrasound frequency and gas-body composition on the contrast agent-mediated enhancement of vascular bioeffects in mouse intestine. Ultrasound Med Biol 26: 307-313.

Miller DL, Li P, Dou C, Gordon D, Edwards CA, Armstrong WF. (2005) Influence of contrast agent dose and ultrasound exposure on cardiomyocyte injury induced by myocardial contrast echocardiography in rats. Radiology 237: 137-143.

Miller DL, Li P, Gordon D, Armstrong WF. (2005) Histological characterization of microlesions induced by myocardial contrast echocardiography. Echocardiography 22: 25-34.

Miller DL, Pislaru SV, Greenleaf JE. (2002) Sonoporation: mechanical DNA delivery by ultrasonic cavitation. Somatic Cell Molec Genetics 27: 115-134.

Miller MW. (2000) Gene transfection and drug delivery. Ultrasound Med Biol 26 Suppl 1: S5962.

Mohan P, Rapoport N. (2010) Doxorubicin as a molecular nanotheranostic agent: effect of doxorubicin encapsulation in micelles or nanoemulsions on the ultrasoundmediated intracellular delivery and nuclear trafficking. Molecular Pharmaceutics 7: 1959-1973.

Negishi Y, Endo Y, Fukuyama T, Suzuki R, Takizawa T, Omata D, Maruyama K, Aramaki Y. (2008) Delivery of siRNA into the cytoplasm by liposomal bubbles and ultrasound. J Control Release 132: 124-130.

Newman CM, Bettinger T. (2007) Gene therapy progress and prospects: ultrasound for gene transfer. Gene Ther 14: 465-475.

Niidome T, Huang L.(2002) Gene therapy progress and prospects: nonviral vectors. Gene Ther 9: 1647-1652. 
Noble ML, Brayman AA, Kuhr CS, Graves SS, Keilman GW, Chen L, Loeb KR, Storb RF, Miao CH. (2011) Effective gene transfer using microbubble-assisted ultrasound therapy in canine livers. American Society of Gene and Cell Therapy 14th Annual Meeting 2011: Oral abstract presentation.

Okada K, Kudo N, Hassan MA, Kondo T, Yamamoto K. (2009) Threshold curves obtained under various gaseous conditions for free radical generation by burst ultrasound Effects of dissolved gas, microbubbles and gas transport from the air. Ultrasonics Sonochem 16: 512-518.

Otani K, Yamahara K, Ohnishi S, Obata H, Kitamura S, Nagaya N. (2009) Nonviral delivery of siRNA into mesenchymal stem cells by a combination of ultrasound and microbubbles. J Control Release 133: 146-153.

Overvelde M, Garbinb V, Sijl J, Dollet B, de Jong N, Lohse D, Versluis M. (2010) Nonlinear shell behavior of phospholipid-coated microbubbles. Ultrasound Med Biol 36: 2080 - 2092.

Phillips LC, Klibanov AL, Wamhoff BR, Hossack JA. (2010) Targeted gene transfection from microbubbles into vascular smooth muscle cells using focused, ultrasoundmediated delivery. Ultrasound Med Biol 36: 1470-1480.

Pislaru SV, Pislaru C, Kinnick RR, Singh R, Gulati R, Greenleaf JF, Simari RD. (2003) Optimization of ultrasound-mediated gene transfer: comparison of contrast agents and ultrasound modalities. Eur Heart J 24: 1690-1698.

Plesset MS, Chapman RB. (1971) Collapse of an initially spherical vapour cavity in the neighbourhood of a solid boundary. J Fluid Mech 47: 283-290.

Porter TM, Smith DAB, Holland CK. (2006) Acoustic techniques for assessing the Optison destruction threshold. J Ultrasound Med 25: 1519-1529.

Porter TR. (2009) The utilization of ultrasound and microbubbles for therapy in acute coronary syndromes. Cardiovasc Res 83: 636-642.

Porter TR, Hiser WL, Kricsfeld D, Deligonul U, Xie F, Iversen P, Radio S. (2001) Inhibition of carotid artery neointimal formation with intravenous microbubbles. Ultrasound Med Biol 27: 259-265.

Postema M, Schmitz G. (2007) Ultrasonic bubbles in medicine: influence of the shell. Ultrasonics Sonochem 14: 438 - 444.

Postema M, van Wamel A, Lancee CT, de Jong N. (2004) Ultrasound-induced encapsulated microbubble phenomena. Ultrasound Med Biol 30: 827-840.

Price RJ, Skyba DM, Kaul S, Skalak TC. (1998) Delivery of colloidal particles and red blood cells to tissue through microvessel ruptures created by targeted microbubble destruction with ultrasound. Circulation 98: 1264-1267.

Qin S, Caskey CF, Ferrara KW. (2009) Ultrasound contrast microbubbles in imaging and therapy: physical principles and engineering. Phys Med Biol 54: R27-57.

Qiu Y, Luo Y, Zhang Y, Cui W, Zhang D, Wu J, Zhang J, Tu J. (2010) The correlation between acoustic cavitation and sonoporation involved in ultrasound-mediated DNA transfection with polyethylenimine (PEI) in vitro. J Control Release 145: 40-48.

Rahim AA, Taylor SL, Bush NL, ter Haar GR, Bamber JC, Porter CD. (2006) Spatial and acoustic pressure dependence of microbubble-mediated gene delivery targeted using focused ultrasound. J Gene Med 8: 1347-1357.

Robinson PB, Blake JR, Kodama T, Shima A, Tomita Y. (2001) Interaction of cavitation bubbles with a free surface. J Appl Phys 89: 8225-8237. 
Sakai T, Kawaguchi M, Kosuge Y. (2009) siRNA-mediated gene silencing in the salivary gland using in vivo microbubble-enhanced sonoporation. Oral Diseases 15: 505-511.

Samuel S, Cooper MA, Bull JL, Fowlkes JB, Miller DL. (2009) An ex vivo study of the correlation between acoustic emission and microvascular damage. Ultrasound Med Biol 35: 1574-1586.

Sankin GN, Yuan F, Zhong P. (2010) Pulsating tandem microbubble for localized and directional single-cell membrane poration. Physical Rev Lett 105: 078101.

Sarkar K, Katiyar A, Jain P. (2009) Growth and dissolution of an encapsulated contrast microbubble: effects of encapsulation permeability. Ultrasound Med Biol 35: 13851396.

Sarvazyan AP, Rudenko OV, Nyborg WL. (2010) Biomedical applications of radiation force of ultrasound: historical roots and physical basis. Ultrasound Med Biol 36: 1379-1394.

Sassaroli E, Hynynen K. (2007) Cavitation threshold of microbubbles in gel tunnels by focused ultrasound. Ultrasound Med Biol 33: 1651-1660.

Shen ZP, Brayman AA, Chen L, Miao CH. (2008) Ultrasound with microbubbles enhances gene expression of plasmid DNA in the liver via intraportal delivery. Gene Ther 15: 1147-1155.

Shima A, Tomita Y, Gibson DC, Blake JR. (1989) The growth and collapse of cavitation bubbles near composite surfaces. J Fluid Mech 203: 199 - 214.

Skyba DM, Price RJ, Linka AZ, Skalak TC, Kaul S. (1998) Direct in vivo visualization of intravascular destruction of microbubbles by ultrasound and its local effects on tissue. Circulation 98: 290-293.

Smith DA, Vaidya SS, Kopechek JA, Huang SL, Klegerman ME, McPherson DD, Holland CK. (2010) Ultrasound-triggered release of recombinant tissue-type plasminogen activator from echogenic liposomes. Ultrasound Med Biol 36: 145-157.

Snyder RO. (1999) Adeno-associated virus-mediated gene delivery. J Gene Med 1: 166-175.

Song J, Chappell JC, Qi M, VanGieson EJ, Kaul S, Price RJ. (2002) Influence of injection site, microvascular pressure and ultrasound variables on microbubble-mediated delivery of microspheres to muscle. J Am Coll Cardiol 39: 726-731.

Song S, Noble ML, Sun SX, Chen L, Brayman AA, Miao CH. (2011b) Optimization of high intensity therapeutic ultrasound and microbubbles for gene delivery into rat liver. American Society of Gene and Cell Therapy 14th Annual Meeting: Oral abstract presentation.

Song S, Shen Z, Chen L, Brayman AA, Miao AA. (2011a) Explorations of high-intensity therapuetic ultrasound and microbubble-mediated gene delivery in mouse liver. Gene Therapy Mar 31. [Epub ahead of print].

Stride E, Saffari N. (2003) On the destruction of microbubble ultrasound contrast agents. Ultrasound Med Biol 29: 563-573.

Stringham SB, Viskovska MA, Richardson ES, Ohmine S, Husseini GA, Murray BK, Pitt WG. (2009) Over-pressure suppresses ultrasonic-induced drug uptake. Ultrasound Med Biol 35: 409-415.

Su CH, Chang CY, Wang HH, Wu YJ, Bettinger T, Tsai CH, Yeh HI. (2010) Ultrasonic microbubble-mediated gene delivery causes phenotypic changes of human aortic endothelial cells. Ultrasound Med Biol 36: 449-458.

Suda T, Suda K, Liu D. (2008) Computer-assisted hydrodynamic gene delivery. Molecular Therapy 16: 1098-1104. 
Talu E, Powell RL, Longo ML, Dayton PA. (2008) Needle size and injection rate impact microbubble contrast agent population. Ultrasound Med Biol 34: 1182-1185.

Taylor SL, Rahim AA, Bush NL, Bamber JC, Porter CD. (2007) Targeted retroviral gene delivery using ultrasound. J Gene Med 9: 77-87.

Tlaxca JL, Anderson CR, Klibanov AL, Lowrey B, Hossack JA, Alexander JS, Lawrence MB, Rychak JJ. (2010) Analysis of in vitro transfection by sonoporation using cationic and neutral microbubbles. Ultrasound Med Biol 36: 1907-1918.

Tsunoda S, Mazda O, Oda Y, Iida Y, Akabame S, Kishida T, Shin-Ya M, Asada H, Gojo S, Imanishi J, Matsubara H, Yoshikawa T. (2005) Sonoporation using microbubble BR14 promotes pDNA/siRNA transduction to murine heart. Biochem Biophys Res Comm 336: 118-127.

Vannan M, McCreery T, Li P, Han Z, Unger E, Kuersten B, Nabel E, Rajagopalan S. (2002) Ultrasound-mediated transfection of canine myocardium by intravenous administration of cationic microbubble-linked plasmid DNA. J Am Soc Cardiogr 15: 214-218.

Villanueva FS. (2009) Ultrasound mediated destruction of DNA-loaded microbubbles for enhancement of cell-based therapies: new promise amidst a confluence of uncertainties? J Am Coll Cardiogr Cardiovasc Imaging 2: 880-882.

Walton CB, Shohet RV. (2009) Tiny bubbles and endocytosis? Circ Res 104: 563-565.

Wang JF, Wu CJ, Zhang CM, Qiu QY, Zheng M. (2009) Ultrasound-mediated microbubble destruction facilitates gene transfection in rat C6 glioma cells. Mol Biol Rep 36: 12631267.

Wang ZX, Wang ZG, Ran HT, Ren JL, Zhang Y, Li Q, Zhu YF, Ao M. (2009) The treatment of liver fibrosis induced by hepatocyte growth factor-directed, ultrasound-targeted microbubble destruction in rats. Clin Imaging 33: 454-461.

Wu J, Nyborg WL. (2008) Ultrasound, cavitation bubbles and their interaction with cells. Advanced Drug Delivery Reviews 60: 1103-1116.

Xie F, Boska MD, Lof J, Uberti MG, Tsutsui JM, Porter TR. (2008) Effects of transcranial ultrasound and intravenous microbubbles on blood brain barrier permeability in a large animal model. Ultrasound Med Biol 34: 2028-2034.

Xing Y, Pua EC, Lu X, Zhong P. (2009) Low-amplitude ultrasound enhances hydrodynamic-based gene delivery to rat kidney. Biochem Biophys Res Commun 386: 217-222.

Yant SR, Huang Y, Akache B, Kay MA. (2007) Site-directed transposon integration in human cells. Nucleic Acids Res 35: e50.

Ye X, Loeb KR, Stafford DW, Thompson AR, Miao CH. (2003) Complete and sustained phenotypic correction of hemophilia B in mice following hepatic gene transfer of a high-expressing human factor IX plasmid. J Thrombosis Haemostasis 1: 103-111.

Yoon CS, Jung HS, Kwon MJ, Lee SH, Kim CW, Kim MK, Lee M, Park JH. (2009) Sonoporation of the minicircle-VEGF(165) for wound healing of diabetic mice. Pharm Res 26: 794-801.

Zarnitsyn VG, Prausnitz MR. (2004) Physical parameters influencing optimization of ultrasound-mediated DNA transfection. Ultrasound Med Biol 30: 527-538.

Zhang G, Song YK, Liu D. (2000) Long-term expression of human alpha1-antitrypsin gene in mouse liver achieved by intravenous administration of plasmid DNA using a hydrodynamics-based procedure. Gene Ther 7: 1344-1349. 
Zheng XZ, Li HL, Du LF, Wang HP, Gu Q. (2009) Comparative analysis of gene transfer to human and rat retinal pigment epithelium cell line by a combinatorial use of recombinant adeno- associated virus and ultrasound or/and microbubbles. Bosn J Basic Med Sci 9: 174-181.

Zhou S, Li S, Liu Z, Tang Y, Wang Z, Gong J, Liu C. (2010) Ultrasound-targeted microbubble destruction mediated herpes simplex virus-thymidine kinase gene treats hepatoma in mice. J Exp Clin Cancer Res 29: 170.

Zhou XY, Liao Q, Pu YM, Tang YQ, Gong X, Li J, Xu Y, Wang ZG. (2009) Ultrasoundmediated microbubble delivery of pigment epithelium-derived factor gene into retina inhibits choroidal neovascularization. Chinese Medical J 122: 2711-2717.

Zhou Y, Cui J, Deng CX. (2008) Dynamics of sonoporation correlated with acoustic cavitation activities. Biophysical J 94: L51-53.

Zhou Y, Kumon RE, Cui J, Deng CX. (2009) The size of sonoporation pores on the cell membrane. Ultrasound Med Biol 35: 1756 - 1760.

Zhou Y, Zhou XY, Wang ZG, Zhu YF, Li P. (2010) Elevation of plasma membrane permeability upon laser irradiation of extracellular microbubbles. Lasers Med Sci 25: 587-594. 


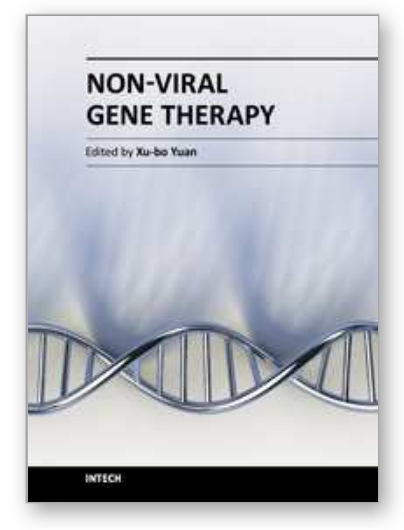

\author{
Non-Viral Gene Therapy \\ Edited by Prof. Xubo Yuan
}

ISBN 978-953-307-538-9

Hard cover, 696 pages

Publisher InTech

Published online 07, November, 2011

Published in print edition November, 2011

This book focuses on recent advancement of gene delivery systems research. With the multidisciplinary contribution in gene delivery, the book covers several aspects in the gene therapy development: various gene delivery systems, methods to enhance delivery, materials with modification and multifunction for the tumor or tissue targeting. This book will help molecular biologists gain a basic knowledge of gene delivery vehicles, while drug delivery scientist will better understand DNA, molecular biology, and DNA manipulation.

\title{
How to reference
}

In order to correctly reference this scholarly work, feel free to copy and paste the following:

Carol H. Miao and Andrew A. Brayman (2011). Ultrasound-Mediated Gene Delivery, Non-Viral Gene Therapy, Prof. Xubo Yuan (Ed.), ISBN: 978-953-307-538-9, InTech, Available from:

http://www.intechopen.com/books/non-viral-gene-therapy/ultrasound-mediated-gene-delivery

\section{INTECH}

open science | open minds

\author{
InTech Europe \\ University Campus STeP Ri \\ Slavka Krautzeka 83/A \\ 51000 Rijeka, Croatia \\ Phone: +385 (51) 770447 \\ Fax: +385 (51) 686166 \\ www.intechopen.com
}

\author{
InTech China \\ Unit 405, Office Block, Hotel Equatorial Shanghai \\ No.65, Yan An Road (West), Shanghai, 200040, China \\ 中国上海市延安西路65号上海国际贵都大饭店办公楼405单元 \\ Phone: +86-21-62489820 \\ Fax: +86-21-62489821
}


(C) 2011 The Author(s). Licensee IntechOpen. This is an open access article distributed under the terms of the Creative Commons Attribution 3.0 License, which permits unrestricted use, distribution, and reproduction in any medium, provided the original work is properly cited. 